\title{
Yaratıcı Örgüt İkliminin Çalışan Sesliliği Üzerindeki Etkisinde Duygusal Zekânın Destekleyici Rolü
} (Araştırma Makalesi)

\author{
Moderating Role of Emotional Intelligence on the Effect of Creative \\ Organizational Climate on Employee Voice
}

Doi: 10.29023/alanyaakademik.670259

Mustafa BABADAĞ

Öğr Gör. Dr., Muğla Sitkı Koçman Üniversitesi, Muğla Meslek Yüksekokulu, Dış Ticaret

Bölümü,

mustafababadag@mu.edu.tr

Orcid No: 0000-0002-0198-7105

\section{Taner DALGIN}

Öğr Gör. Dr., Muğla Sitkı Koçman Üniversitesi, Muğla Meslek Yüksekokulu, Seyahat, Turizm ve Ĕ̈lence Hizmetleri Bölümü,

tanerdalgin@mu.edu.tr

Orcid No: 0000-0002-7645-1989

Bu makaleye atıfta bulunmak için: Babadă̆, M., \& Dalgın, T. (2020). Yaratıcı Örgüt İkliminin Çalışan Sesliliği Üzerindeki Etkisinde Duygusal Zekânın Destekleyici Rolü. Alanya Akademik Bakış, 4(3), Sayfa No. 1057-1081.

Anahtar kelimeler:
Yaratıcı Örgüt İklimi,
Çalışan Sesliliği,
Duygusal Zekấ
Makale Geliş Tarihi:
04.01.2020
Kabul Tarihi:
02.09.2020

Keywords:

Creative

Organizational

Climate, Employee

Voice Behavior,

Emotional

Intelligence

\section{ÖZET}

$\overline{\text { Araştırma örgütler için olumlu bir davranış olarak değerlendirilen çalışan }}$ sesliliği davranışı üzerinde yaratıcı örgüt iklimi algısının etkisi olup olmadığını belirlemeyi amaçlamaktadır. Ayrıca araştırma böyle bir etki varsa bu etkide çalışanların duygusal zekâlarının destekleyici rolünün bulunup bulunmadığını ortaya çıkarmayı istemektedir. $\mathrm{Bu}$ iki amaç doğrultusunda bir mobilya işletmesinde görev yapan çalışanlardan anket yöntemi ile veri toplanmıştır. SPSS ve AMOS programları ile analizler gerçekleştirilmiş ve hipotezler sınanmıştır. Araştırma sonucunda yaratıcı örgüt ikliminin çalışan sesliliği davranışını pozitif yönde ve anlamlı olarak etkilediği ayrıca duygusal zekânın bu ilişki de destekleyici role sahip olduğu sonucuna ulaşılmıştır. Bunun yanında duygusal zekâ boyutlarından yalnızca duyguların pozitif kullanımının destekleyici rolünün anlamlı olduğu tespit edilmiştir.
ABSTRACT
The research aims to determine whether creative organizational climate perception has an impact on employee voice behavior which is considered as a positive behavior for organizations. The research also aims to identify the moderator role of emotional intelligence on the impact of creative organizational climate on employee voice behavior. For these two purposes, data were collected from the employees working in a furniture company by survey method. SPSS and AMOS programs were used for analysis and 
hypothesis testing. As a result of the research, it was concluded that the creative organizational climate has a positive and significant effect on employee voice behavior and also emotional intelligence has a moderating role in this relationship. In addition, it was found out that only moderating role of the positive utilization was significant among the dimensions of emotional intelligence.

\section{GİRİş}

Kurumsal başarının dış çevre koşulları ile birlikte kurum içerisindeki çalışanların niteliklerine, davranışlarına, yönetsel politikalara ve yöneticilerin göstermiş oldukları davranışlara bağlı olması durumu (Zengin, 2019) örgütsel davranış konularının temel dayanağını oluşturmaktadır. Çalışanların yaptıkları iş ile ilgili fikirlerini, problemlerini ve problemlere ilişkin çözüm önerilerini özgür şekilde ifade edebildikleri örgütsel yapıların, daha yönetilebilir olduğu ve yöneticinin yönetim becerilerini daha net sergilemesine imkân sağlayacağı söylenebilir. Çalışanların sahip olduğu bilgi, fikir ve deneyimlerin örgüt kültür ve ruhuna kazandırılması işletmenin rekabet gücüne özgün bir nitelik kazandıracaktır. Çalışanların iş ile ilgili bilgisini, fikrini, öngörüsünü veya olumsuz tepkisini ifade etmesini teşvik edecek yönetsel ortamın oluşturulmasının, örgütsel değişime ve gelişime uyum sağlayabilecek ve destekleyecek örgütsel yapıların oluşturulmasına katkı sağlayacağı ön kabulü bu çalışmanın temel varsayımını oluşturmaktadır. Çalışan sesliliğinin artması ve örgüt içinde olumlu etkilere yol açabilmesi, ancak üst yönetimin çalışanlarının düşünce ve önerilerine önem vermesi, işleriyle ilgili sorunlarını açıklamaları için teşvik etmesi ve bu uygulamaların sonucunda çalışanların değişim için kendilerinin etkili olabileceğine inanmasıyla mümkün olacaktır (Bowen ve Blackmon, 2003).

Çalışan sesliliğini teşvik edecek bir örgütsel iklimin varlığı, bu davranışın ortaya çıkmasında oldukça önemli olacaktır. Yaratıcı örgüt ikliminin özelliklerini taşıyan bir örgütte çalışan sesliliğinin ortaya çıkma olasılığının daha yüksek olacağı düşünülmektedir (Lundmark ve Björkman, 2011: 607). Bu durumla bağlantılı olarak çalışmada öncelikle yaratıcı örgüt iklimi ve çalışan sesliliği arasındaki ilişki araştırılmıştır. Bununla birlikte, yaratıcı örgüt iklimini daha doğru algılamak ve bu örgütsel iklimin çalışan üzerinde yarattığı duygusal etkileri daha iyi özümsemek, çalışanın duygusal zekâ düzeyiyle bağıntılı olacaktır. Bu nedenle çalışmada yaratıcı örgüt iklimi ve çalışan sesliliği ilişkisinde çalışanın duygusal zekâ düzeyinin destekleyici değişken olarak etkisi de araştırılmıştır.

Yerli ve yabancı literatürde örgütsel seslilik, yaratıcı örgüt iklimi ve duygusal zekâ konularını ele alan birçok araştırma olmakla birlikte, ilgili değişkenleri birlikte ele alan ve arasındaki ilişkiler üzerine odaklanan herhangi bir araştırmaya rastlanılmamıştır. Araştırmada bağımlı değişken olarak ele alınan çalışan sesliliği davranışı örgütün işleyişiyle ilgili birçok olumlu sonucu beraberinde ortaya çıkarması beklenilen olumlu bir örgütsel davranıştır. Yaratıcı örgüt iklimi ve örgütsel seslilik ilişkisini ve bu ilişki üzerinde duygusal zekânın düzenleyici etkisini belirlemeyi amaçlayan bu çalışmanın öncelikle literatüre özgün bir katkıda bulunacağ1 söylenebilir. Ayrıca çalışan sesliliğinin, ilişkili olduğu örgütsel iklimin özelliklerini ortaya koymak ve duygusal zekânın bu ilişki üzerindeki düzenleyici etkisinin olup olmadığını belirlemek, örgütsel iklimi şekillendiren yönetici kadrolara uygulamaya yönelik önemli bilgiler sağlayacaktır. 


\section{KAVRAMSAL ÇERÇEVE VE HIPOTEZLER}

\subsection{Yaratıcı Örgüt İklimi}

Örgüt iklimi, çalışanların örgüt içindeki ortama ilişkin algılarını etkileyen pek çok uygulama ve prosedürden oluşan çok boyutlu bir yapıyı ifade etmektedir. Örgüt iklimi, örgütü diğer örgütlerden ayırarak ona belli bir kimlik kazandıran, örgütteki personel tarafından algılanan veya onların davranışları üzerinde etkili olan bireysel, örgütsel ve çevresel özellikler bütününü ifade eder (Yılmaz vd., 2014: 247). Örgüt iklimi, çalışanların davranışlarını çeşitli şekillerde etkileyen, örgüt içindeki kuralların ve uygulamaların etkisiyle oluşan bir ortam olarak değerlendirilebilir. Örgüt içindeki kurallar ve uygulamalar bireyler tarafindan farklı şekillerde algılanabileceği için örgüt iklimini algısal bir yapı olarak değerlendirmek daha doğru bir yaklaşım olacaktır. Örgütte çalışan bireyin, örgütsel iklimi destekleyici ve cesaretlendirici olarak algılaması, olumlu örgütsel davranışlar sergilemesini doğrudan veya dolaylı olarak destekleyecektir (Gündüz Çekmecelioğlu, 2006: 299). Örgütsel iklimin uygun olmadığı bir ortamda ise çalışanların örgütsel faaliyetlere isteyerek katılması, sahip olduğu kazanımları örgüt ile rahatlıkla paylaşması veya işiyle ilgili motivasyonunu yüksek tutması mümkün olamayacaktır (Zengin, 2019: 333).

Örgütsel yaratıcılık ve yenilikçiliğin temelinde ise örgütü oluşturan bireylerin yaratıcı fikirleri ve bu fikirlerin ortaya çıkmasını sağlayacak olan destekleyici örgüt iklimleri vardır (Amabile, 1988; Woodman, vd., 1993). Yaratıcılığı ele alan geleneksel psikolojik yaklaşımlarda, yaratıcı bireylerin özellikleri üzerine odaklanılmaktadır. Ancak, yaratıcı davranışın düzeyi ve sıklığı üzerinde sosyal çevrenin etkisini yadsıyan bir bakış açısı yaratıcı davranışı açıklamakta yetersiz kalmaktadır (Amabile vd., 1996: 1154). Modern yaklaşımlar ise tüm bireylerin yaratıcı davranışlarla ilgili normal kapasiteleri olduğunu ve bulundukları ortamda yaratıcı çıktılar üretebileceğini kabul ederek, bireyin yaratıcılığında sosyal çevrenin önemi üzerine odaklanmaktadır. Modern yaklaşımın bakış açısını temel alan birçok araştırmacı iş çevresinin yaratıcılık üzerindeki rolünü incelemiş ve destekleyici bir örgüt ikliminin yaratıcılık üzerinde pozitif etkiye sahip olduğunu bulgulamıştır (Amabile vd., 1996; Shalley vd., 2000; Cummings ve Oldham, 1997; Dubina, 2013; Gündüz Çekmecelioğlu, 2006; Olsson vd., 2019; Thiruvenkadam ve Sampath Kumar, 2018). Bu bakış açısıyla ortaya çıkan yaratıcı örgüt iklimi kavramı, örgütün sosyal çevresi ile yaratıcılık ve inovasyon ilişkisine ait algıları kapsamaktadır (Lundmark ve Björkman, 2011: 607). Bireylerin algısına dayanan yaratıc1 örgüt iklimi literatürde genellikle çok boyutlu bir yap1 olarak değerlendirilmekte ve bu konuda yapılan araştırmaların birçoğu Ekvall (1996) tarafından geliştirilen yaratıcı örgüt iklimi boyutlarını temel almaktadır. Ekvall tarafından ortaya atılan ve yaratıcı örgüt iklimini oluşturan boyutlar işin iddialı olması, özgürlük, fikirsel destekleme, güven/açıklık, dinamizm/canlılık, eğlencelilik/mizah, müzakare, çatışma, risk alma ve fikir üretme zamanı olarak adlandırılmaktadır. Bu boyutlar aşağıda kısaca açıklanmıştır (Ekvall, 1996).

İşin iddialı olması: Yüksek zorluğa sahip örgütsel iklim çalışanların işinden zevk almasını ve işini daha anlamlı bulmasını sağlayacaktır. Bunun sonucunda çalışanlar enerjilerini iş için harcamaya istekli olacaktır (Ekvall, 1996). Belirli derecede zorluğa sahip işlerin, sorumluluk ve inisiyatif kullanmayı gerektirdiği için, yaratıcılığı ve içsel motivasyonu artırdığ genel olarak kabul edilmektedir (Gündüz Çekmecelioğlu, 2002). 
Özgürlük: Çalışanların kendi işlerini nasıl tasarlayacakları ile ilgili özgürlüğe sahip olmasını ifade etmektedir. Çalışanların problemleri ve alternatifleri tartışabilmesi, farklı türde planlar yapabilmesi ve inisiyatif kullanabilmesi yaratıcı örgüt ikliminin özgürlük boyutuyla ilgilidir.

Fikirsel destekleme: Çalışanların işleriyle ilgili yeni fikirler ortaya koyduklarında yönetim tarafindan desteklenmelerini ifade etmektedir.

Güven/açıklık: Çalışanların işyeri ilişkilerinde duygusal olarak kendilerini güvende hissetmelerini ifade etmektedir. Bu güven hem çalışanların kendi aralarında, hem de çalışanlar ve yöneticiler arasında olmalıdır. Duygusal güvenin yüksek düzeyde olduğu örgütsel iklimde çalışanlar yeni fikirlerini öne sürmeye kolaylıkla cesaret edebilecektir.

Dinamizm/canlılık: Örgüt içerisinde olumlu bir enerjinin ve işleyişteki heyecanın varlığını ifade etmektedir. Dinamik durumlar içerisinde olmak, konuların ele alınış şekillerinde ve düşünme yöntemlerinde sürekli değişikliklerin olması zorunluluğu sebebiyle, örgüt içerisinde yaratıcı örgüt iklimini güçlendirecektir.

Eğlencelilik/mizah: İş yerinde şaka yapmaya ya da kahkaha atmaya imkân sağlayacak rahat bir ortamın varlığını ifade etmektedir.

Müzakere: Bakış açılarının, fikirlerin, farklı deneyimlerin ve bilgilerin karşı karşıya gelmesi ve çatışması durumunu ifade etmektedir. Müzakereye açık örgütlerde çalışanların sesi oldukça fazla duyulur ve çalışanlar fikirlerini ortaya koymaya oldukça heveslidir.

Çatışma: Örgüt İçerisinde kişisel ve duygusal gerginliğin varlığını ifade etmektedir. Örgütsel iklimde gerginlik düzeyi yüksek olduğunda kişiler ve gruplar birbirlerinden hoşlanmaz ve aralarında rekabet ortaya çıkar.

Risk alma: Örgütteki belirsizliğe olan toleransı ifade etmektedir. Yüksek risk alma durumunda örgütte kararlar ve eylemler hızlı şekilde gerçekleşir, ortaya çıkan firsatlardan yararlanılır ve detaylı araştırmaların ve analizlerin yerini somut denemeler alır.

Fikir üretme zamanı: Çalışanların yeni fikirleri tasarlayabilmek için sahip olduğu zaman miktarını ifade etmektedir. Çalışanlara yeni fikirlerini ve önerilerini tasarlayabilmeleri için rutin işlerin dışında fazladan zaman sağlamak yaratıcı örgüt iklimini geliştirecektir.

Yaratıcı örgüt iklimi boyutlarından bazılarının çalışan sesliliği ile yakından ilişkili olduğu görülmektedir. Özellikle özgürlük, fikirsel destekleme, güven/açıklık, müzakere boyutları yaratıcı örgüt ikliminin bir boyutu olmakla birlikte, içeriği gereği çalışan sesliliğini de doğrudan destekleyecektir. Bu anlamsal ilişkiler sebebiyle yaratıcı örgüt iklimi ve çalışan sesliliği ilişkisinin irdelenmesi literatüre önemli katkı sağlayacaktır.

\subsection{Yaratıcı Örgüt İklimi ile Çalışan Sesliliği Arasındaki İlişki}

İşgörenlerin örgütsel problemler ve örgütsel iyileştirmeler hakkındaki fikir, bilgi ve düşüncelerini kasıtlı olarak esirgemesini ve bu durumun kolektif olarak gerçekleşmesini ifade eden örgütsel sessizlik kavramı (Morrison ve Milliken, 2000: 708) örgütlerde istenilmeyen bir durum olmakla birlikte, farkına varılması ve müdahale edilmesi oldukça zor bir örgütsel tutumdur. Örgütsel sessizlik, bireysel bir davranış olmakla beraber, kişilerin birbirlerinden etkilenmesi sonucunda örgüt içinde bir iklim haline dönüşebilmektedir (Alparslan ve Kayalar, 2012). Örgütsel sessizliğin örgüt üzerinde ortaya çıkaracağı olumsuzlukları reaktif bir yaklaşımla çözmenin mümkün olmaması sebebiyle, literatürde son yıllarda proaktif bir 
yaklaşımla, çalışanların örgüt içerisinde örgütü eleştirmekten çok geliştirmek amacına hizmet eden yapıcı bir tartışmayı içeren destekleme, geliştirme ve iyileştirme niyetli davranışlarını (Van Dyne ve LePine, 1998) ifade eden çalışan sesliliği kavramı üzerine odaklanılmıştır.

Çalışan sesliliği, iş ile ilgili önerileri beyan etme, yöneticilerle sorunları tartışma, sıkıntıları ve şikâyetleri ifade etme gibi (Saunders vd., 1992) çalışanın aktif olarak ortaya koyduğu ve örgütsel sessizlik davranışlarına kıyasla kolaylıkla fark edilebilecek olumlu tutumları ifade etmektedir. Aktif ve yapıcı bir davranış olarak kabul edilen (Farrell ve Rusbult, 1992) çalışan sesliliği, muhalefet, şikayetçi olmak ya da protesto etmekten çok destekleyici, geliştirme ve iyileştirme amaçlı davranışları ifade eden bir kavramdır (Van Dyne ve LePine, 1998: 110). Örgütsel seslilik, çalışanların görüş, düşünce, fikir ve sahip olduğu bilgileri zorlama olmaksızın kendi istekleriyle örgütsel faaliyetlere katkı sunmak amacıyla ifade etmesidir (Göktaş Kulualp, 2016: 746).

Örgütsel sesin artması ve olumlu etkilere sebep olabilmesi için üst yönetim tarafından çalışanların düşüncelerine ve önerilerine önem verilmesi, işleriyle ilgili sorunlarını açıklamaları için teşvik edilmesi ve bunun sonucunda çalışanların değişim için etkili olduklarına inanmaları gerekmektedir (Bowen ve Blackmon, 2003: 1394). Çalışanın seslilik davranışı sergilemesi, büyük ölçüde örgütteki sorunların düzeleceği inancına sahip olması ve bu sorunların çözümüne yönelik olumlu tutum geliştirmesi sonucunda mümkün olacaktır (Whitney ve Cooper, 1989: 535). Bununla birlikte, örgüte fayda sağlayan, çalışan sesliliği, bu davranış1 sergileyen bireyler için çeşitli risk ve maliyetler de içermektedir. Statükoyu sorgulamak zorlayıcı otorite veya kazanılmış çıkarlar üzerinde rahatsızlık hissi yaratabilmekte ve bunun sonucunda çalışanın imajı veya sosyal ilişkileri örgüt içinde zarar görebilmektedir (Liu, Zhu ve Yang, 2010: 191).

Örgüt içerisindeki seslilik davranışları genel olarak kabullenici seslilik, savunmacı seslilik ve örgüt yararına seslilik olmak üzere üç temel boyutta ele alınmaktadır (Zengin, 2019: 316). Kabullenici seslilikte, çalışanlar guruptan dişlanma korkusu sebebiyle kendi görüşlerini açıklamak yerine örgütteki düşünce ortamını değerlendirerek grubun ortak görüşlerine katılarak kabullenici bir seslilik gösterme eğilimi göstermektedir (Bowen ve Blackmon, 2003). Savunmacı seslilik ise, çalışanların örgüt ortamında haksızlığa uğradıklarını düşündükleri durumlarda, eleştiri ve şikayetlerini bu duruma yanıt olarak açığa çıkarmalarını ifade etmektedir (Ellis ve Van Dyne, 2009). Örgüt yararına seslilik ise işbirliği motivasyonuna bağlı kalınarak işle ilgili fikirler, bilgiler ve düşüncelerin beyan edilmesini kapsamaktadır (Van Dyne ve LePine, 1998). Özellikle örgüt yararına seslilik kendini yenileyebilen ve sürekli gelişen örgütsel yapıların oluşturulmasında üzerinde önemle durulması gereken bir konudur.

Konuyla ilgili literatüre bakıldığında çalışan sesliliği davranışının örgütlerde birçok olumlu sonuca neden olduğu görülmektedir. Örneğin çalışan sesliliği ile örgütler daha iyi kararlar alabilmekte ve örgütsel hataları tespit edebilmekte (Morrison ve Milliken, 2000), örgütlerin öğrenme davranışları gelişmekte (Argyris ve Schön, 1978), görev verimliliği artmakta ve çalışma koşulları iyileşmektedir (Morrison, 2011). Bunun yanında, çalışanların örgüte ilişkin olumlu tutumları (Morrison ve Milliken, 2000), ekstra rol performansları (Van Dyne ve LePine, 1998), örgütsel bağlılıkları (Prasadika ve Nishanthi, 2018), iş tatminleri (Alfayad ve Arif, 2017), örgütsel etkililikleri (Jha vd., 2019) ve işe bağlanma duyguları (Jha vd., 2019) artarken, işten ayrılma niyetleri (Lam vd., 2016) ve tükenmişlik duyguları (Thohiroh ve Satrya, 2019) azalmaktadır. Bu sonuçlarından dolayı çalışan sesliliği örgütler için önemli bir 
davranış olarak görülmekte ve hangi faktörler ile ortaya çıkabileceği çeşitli araştırmalar ile belirlenmeye çalışılmaktadır. Örgütsel sesliliği ortaya çıkaran faktörler arasında çalışanların kişilik özellikleri (LePine ve Van Dyne, 2001), örgüt kültürü (Morrison, 2011; Stamper ve Van Dyne, 2001), örgütsel destek algısı (Tucker vd., 2008) ve örgütsel adalet (Makens, 2016; Tangirala ve Ramanujam, 2008) gibi unsurlar bulunmaktadır. Ayrıca, örgütsel seslilik davranışı ile dönüştürücü liderlik (Detert and Burris, 2007; Duan vd., 2017; Wang vd., 2019), etik liderlik (Walumbwa and Schaubroeck, 2009), otantik liderlik (Hsin-Hua, 2012), lider üye etkileşimi (Botero ve Van Dyne, 2009), görev odaklı liderlik (Bulut ve Meydan, 2018) arasındaki pozitif yönlü ilişkiyi ortaya koyan araştırmalar mevcuttur. $\mathrm{Bu}$ araştırmada ise yaratıcı örgüt ikliminin seslilik davranışını ortaya çıkaracak bir başka faktör olduğu düşünülmektedir. Çünkü yaratıcılık ve inovasyon örgütün her düzeyinde bilginin paylaşılmasına ve oluşturulmasına dayanmaktadır (Sundgren vd., 2005). Bu nedenle en alttaki çalışandan en üstteki çalışana kadar tüm çalışanların yaratıcılık ve inovasyon için örgütlerde bilgilerini paylaşması gerekmektedir. Yaratıcı örgüt ikliminin varlığı ile çalışanlar bir anlamda örgüt içerisinde böyle bir atmosfer algılamaktadırlar. Çünkü yaratıcı örgüt iklimi ile çalışan örgütün yaratıcılığa verdiği değeri hissetmekte ve bunu sağlamak adına örgütün her türlü desteğe açık olduğunu görmektedir (Lundmark ve Björkman, 2011: 607). Bu nedenle yaratıcı örgüt ikliminin çalışan sesliliği davranışını arttırması beklenmektedir. Çünkü çalışanlar yaratıcı örgüt ikliminin varlığını algıladıklarında fikrini paylaşmanın olumsuz karşılanmayacağını hatta bunun örgüt ve yönetim tarafından yaratıcılığı ortaya çıkarmak için istenen bir davranış olduğunu düşünebilmektedir. Ayrıca Morrison ve Milliken (2000) çalışan sessizliğini araştırdıkları çalışmalarında bu düşünceyi desteklemektedirler. Çünkü Morrison ve Milliken (2000) sessizliğin yöneticinin tutum ve inançlarının bir sonucu olduğunu belirtmekte ve yöneticilerden gelebilecek olumsuz geri bildirim korkusunun sessizliğin yaratılmasına ve gelişmesine katkıda bulunduğunu ileri sürmektedirler. $\mathrm{Bu}$ açıdan bakıldığında olumsuz geri bildirimin olduğu bir ortamda susmayı tercih eden bir çalışanın olumsuz geri bildirim korkusu yaşamayacağı yaratıcı örgüt ikliminde düşündüklerini belirtmesi beklenen bir davranış olacaktır. Bundan dolayı yaratıcı örgüt ikliminin çalışan sesliliği davranışı üzerinde aynı yönlü etkiye sahip olacağı düşünülmektedir. Ancak literatürde bu ilişkinin varlığını ortaya koyan bir çalışmaya rastlanmamıştır. Bunun yanında farklı bir örgüt iklimi unsuru olan örgütsel etik iklim ile çalışan sesliliği arasındaki ilişkiyi araştıran Ling ve Liu (2016) örgütsel etik iklimin çalışan sesliliğini olumlu yönde etkilediğini destekleyen bulgular elde etmiştir. Yaratıcı örgüt iklimi ve çalışan sesliliği konularının teorik ilişkisi ve literatürdeki diğer çalışmalarla bağlantılı olarak bu değişkenler arasındaki ilişkiyi ortaya koymak amacıyla aşağıdaki hipotez geliştirilmiştir.

H1: Yaratıcı örgüt iklimi çalışan sesliliği davranışını pozitif yönde etkilemektedir.

\subsection{Yaratıcı Örgüt İklimi, Duygusal Zekâ ve Çalışan Sesliliği Arasındaki İlişki}

Literatürde farklı şekillerde açıklanan duygusal zekâ kavramı Salovey ve Mayer (1990)’e göre "Bireyin kendisi ve başkalarının duygularının farkında olması, sorunların çözümünde davranışlarını kontrol etmesi, bunları ayırt edebilmesi, başarıya ulaşması, insanlarla iyi ilişkiler kurmasında ve bu ilişki süreçlerinde elde ettiği bilgiyi, düşünce ve eyleminde etkin kullanabilmesi” olarak ifade edilmektedir. Bar-On (2005) ise duygusal zekâ kavramını bireyin etrafında oluşan baskı ve beklentilere karşı başarılı bir biçimde başa çıkabilmesinde bireye destek veren, bireysel, duygusal ve sosyal yetkinlik ile kabiliyet kapasitesinin tümü olarak ifade etmiştir. Duygusal zekâ, duyguları doğru değerlendirebilme, bunları doğru 
kullanabilme ve yönetebilme, sahip olunan duyguların diğer insanlar üzerindeki etkilerini anlayabilme gibi yetenekleri kapsamaktadır (Law, Wong ve Song, 2000: 485). Acar (2002: 56) duygusal zekâ kavramını, bireyin kendisiyle ve başkalarıyla başa çıkabilmeyi kolaylaştıran duyguları tanıma, anlama ve etkin biçimde kullanabilme yeteneği olarak tanımlamıştır. Duygusal zekâ, bireyin yaşamındaki başarısının belirleyicisi olarak, öncelikle kendine ait duygularını fark edip tanıması, onları uygun şekilde kontrol edebilmesi ve yaşamındaki hedefleri için öz motivasyonunu gerçekleştirebilmesi ile ilişkili bireysel yetenek ve becerileri kapsamaktadır (Acar, 2002: 55).

Goleman, duygusal zekâyı öz bilinç, kendi duygularını yönetme, kendini motive etme, empati ve sosyal beceriler olmak üzere 5 boyutta toplamıştır (Goleman, 2000: 393-394). Öz bilinç, bireyin kendi ruh halini, duygularını ve güdülerini anlaması, bunların başkaları üzerindeki etkilerinin farkına varması ve buna bağlı olarak özgüven geliştirmesini ifade etmektedir. Kendi duygularını yönetme boyutu ise bireyin sahip olduğu duygu, düşünce ve güdüleri kontrol edebilmesi ile ilgili becerileri kapsamaktadır (Çetinkaya ve Alparslan, 2001: 366). Kendi duygularını yönetme yeterliliğine sahip olanlar, olumsuz duyguların etkisinden çabuk kurtulmakla birlikte, duyguları gerektiği düzeyde dikkate alarak, daha sağlıklı karar verme süreçleri geliştirir ve uygularlar (Goleman, 2002: 16, 17). Motivasyon, bireylerin belirli bir amacı gerçekleştirmek üzere kendi arzu ve istekleri ile davranmaları ve çaba göstermelerini ifade etmektedir (Koçel, 2005: 633). Duygusal zeka kapsamında motivasyon, bireylerin belirledikleri hedeflerle ilgili zorluklarla karşılaştıklarında yada başarısızlığa uğradıklarında, tekrar hedefe odaklanabilme güçlerini ifade etmektedir. Empati başka insanların duygusal yapısını anlama yeteneği, insanların duygusal tepkilerini tahmin ederek, onlara uygun davranış biçimleri geliştirme becerisidir (Goleman, 2002: 18). Soysal beceri, ilişkileri yürütme, şebeke kurma, ortak zemin bulma ve yakınlık sağlama yeteneği sayesinde bireyin sosyal durumlara ve ilişki haritalarına ait güçlü farkındalığını ifade etmektedir (Goleman, 2002: 18).

Chan (2004) ise duygusal zekâ kavramını duygusal değerlendirme (emotional appraisal), pozitif duygusal yönetim (positive regulation), empatik duyarlılık (empathic sensitivity) ve duyguların pozitif kullanımı (positive utilization) olmak üzere dört alt boyutta ele almıştır. Duygusal değerlendirme boyutu benlikteki duyguların algılanması, farkına varılması ve anlaşılması şeklinde açıklanırken, pozitif duygusal yönetim boyutu kişinin olumlu beklenti ve bakış açısıyla duygusal modunu düzenleyebilme becerisini ifade etmektedir. Empatik duyarlılık boyutu başkalarının duygularının farkına varmadaki genel hassaslığı ve empati kurabilme becerisini kapsamaktadır. Duyguların pozitif kullanımı ise yeni fikirleri değerlendirmek ve üretmek için duyguların olumlu şekilde kullanılmasını ifade etmektedir (Chan, 2004).

Farklı şekillerde boyutlandırılan duygusal zekânın bireylerin ne hissettiklerini anlaması, güçlü ve zayıf yönlerinin farkına varmasının bir sonucu olarak özellikle iş hayatında doğru ve sağlıklı kararların alınabilmesine yardımcı olduğu söylenebilir (Adsız, 2016). Ayrıca duygusal zekânın örgütler açısından birçok olumlu sonuca yol açtığına inanılmaktadır. Nitekim Ahmad ve arkadaşları (2017) Lübnan'da üst düzey banka yöneticileri üzerinde yaptıkları çalışma sonucunda duygusal zekânın kariyer bağlılığı ile pozitif yönlü, işten ayrılma niyeti ile negatif yönlü anlamlı ilişkiye sahip olduğunu belirlemişlerdir. O'Boyle ve arkadaşları (2010) ise yapmış oldukları meta analiz çalışması sonucunda duygusal zekânın iş performansı ile ilişkili olduğunu tespit etmişlerdir. Carmeli (2003) ise İsrail'de yöneticiler 
üzerinde gerçekleştirdikleri araştırma ile duygusal zekânın iş tatmini, duygusal bağlılık, kariyer bağlılığı, görev performansı, bağlamsal performans ile pozitif ilişkili olduğu; örgütten çekilme niyeti ile negatif ilişskili olduğu sonucuna ulaşmıştır. Bu olumlu sonuçlarının yanında duygusal zekânın çalışan sesliliği üzerinde de olumlu bir etki oluşturacağ 1 ve çalışan sesliliği davranışının ortaya çıkmasına imkân yaratacağına inanılmaktadır. Çünkü duygusal zekâsı yüksek olan kişiler daha önce de belirtildiği gibi başkalarının duygularını doğru yorumlayarak, onlara uygun davranış biçimleri geliştirmektedirler. Aynı zamanda bu kişiler belirledikleri hedeflerle ilgili zorluklarla karşılaştıklarında veya başarısız olduklarında, tekrar hedefe odaklanabilmektedirler. Bu nedenle duygusal zekâsı yüksek olan kişiler seslilik davranışında bulunduklarında yöneticilerin bu konuda nasıl davranacağını önceden tahmin edebilecekler ve sorun yaşasalar bile bunun aşılabilecek bir problem olacağını düşünebileceklerdir. Bunun sonucunda ise bu kişiler daha çok seslilik davranışında bulunabileceklerdir. Literatürde bu düşünceyi destekleyen sınırlı sayıda çalışma bulunmaktadır. Swain (2019) yaptığı araştırmada liderin duygusal zekâ düzeyinin, çalışan sesliliğini pozitif olarak etkilediğini ortaya koymuştur. Grant (2013) çalışmasında duyguları düzenleyebilme bilgisinin ve stratejisinin, çalışan sesliliğinin şiddetini şekillendirdiği bulgusuna ulaşmıştır. Göktaş Kulualp (2016) içsel kontrol odağı ve örgütsel seslilik arasındaki ilişkiyi ele aldığı çalışmasında içsel kontrol odağının, çalışan sesliliğini pozitif yönde etkilediğini ortaya koymuştur. Liu ve Gu (2018) Çin'de farklı sektörlerdeki çalışanlar üzerinde yaptıkları araştırmada işe katılım ve çalışan sesliliği ilişkisinde duygusal zekânın düzenleyici etkiye sahip olduğu bulgusunu elde etmiştir. Chen (2018) ise Çin'de 214 çalışan ile gerçekleştirdiği araştırma sonucunda duygusal zekânın yapıcı çalışan sesliliği davranışı üzerinde pozitif yönlü ve güçlü bir etkiye sahip olduğu ve bu etkide kapsayıcı liderliğin moderatör rolünün bulunduğu bulgusuna ulaşmıştır.

Bu çalışmada ise duygusal zekânın, yaratıcı örgüt iklimi ile çalışan sesliliği arasındaki ilişkide destekleyici/moderatör role sahip olacağı düşünülmektedir. Bu ilişkiyi araştıran bir çalışmaya literatürde rastlanılmamıştır. Ancak duygusal zekânın başka değişkenler arasında moderatör role sahip olduğunu ortaya koyan çalışmalar bulunmaktadır. Örneğin Novita, Musnadi ve Ibrahim (2018) gerçekleştirdikleri araştırma sonucunda davranışsal kabalığın üretkenlik karşıtı iş davranışlarına etkisinde duygusal zekânın moderatör role sahip olduğunu belirlemişlerdir. Gündüz (2017) ise inşaat, gıda, sigorta ve bilgi iletişim sektörlerinde faaliyette bulunan işletmeler üzerinde gerçekleştirdiği çalışmada ruhsal liderliğin sinizm üzerindeki etkisinde duygusal zekânın moderatör role sahip olduğunu tespit etmiştir. Prentice (2013) ise ABD'de turizm sektöründe yapmış olduğu araştırmada duygusal emeğin tükenmişlik üzerindeki etkisinde duygusal zekânın moderatör role sahip olduğu sonucuna ulaşmıştır. Yin (2010) ise 170 kişi üzerinde yapmış olduğu araştırmada negatif duyguların üretkenlik karşıtı iş davranışları üzerindeki etkisinde duygusal zekânın moderatör role sahip olduğunu belirlemiştir. Araştırma değişkenleriyle ilgili literatürdeki bu araştırmalar, duygusal zekânın yaratıcı örgüt iklimi ve örgütsel seslilik ilişkisinde düzenleyici değişken olarak etkisinin sınanmasını teorik bir alt yapı oluşturmaktadır. Ayrıca duygusal zekânın duygusal değerlendirme, pozitif duygusal yönetim, empatik duyarlılık ve duyguların pozitif kullanımı alt boyutlarının da yaratıcı örgüt iklimi çalışan sesliliği ilişkisinde destekleyici etkiye sahip olacağı öngörülmektedir. Duygusal zekânın ve duygusal zekâ boyutlarının araştırma değişkenleri ilişkisindeki düzenleyici etkisini belirlemeye yönelik olarak aşağıdaki hipotezler geliştirilmiştir. 
H2: Yaratıcı örgüt ikliminin çalışan sesliliği davranışına etkisinde duygusal zekâ destekleyici rol üstlenir; yani, duygusal zekânın yüksek olduğu bir durumda yaratıcı örgüt iklimi çalışan sesliliğini daha fazla etkiler.

H2a: Yaratıcı örgüt ikliminin çalışan sesliliği davranışına etkisinde duygusal değerlendirme boyutu destekleyici rol üstlenir; yani, duygusal değerlendirmenin yüksek olduğu bir durumda yaratıcı örgüt iklimi çalışan sesliliğini daha fazla etkiler.

H2b: Yaratıcı örgüt ikliminin çalışan sesliliği davranışına etkisinde pozitif duygusal yönetim boyutu destekleyici rol üstlenir; yani, duygusal yönetimin yüksek olduğu bir durumda yaratıc1 örgüt iklimi çalışan sesliliğini daha fazla etkiler.

H2c: Yaratıcı örgüt ikliminin çalışan sesliliği davranışına etkisinde empatik duyarlılıkları boyutu destekleyici rol üstlenir; yani, empatik duyarlılı̆̆ın yüksek olduğu bir durumda yaratıcı örgüt iklimi çalışan sesliliğini daha fazla etkiler.

H2d: Yaratıcı örgüt ikliminin çalışan sesliliği davranışına etkisinde duyguların pozitif kullanımı boyutu destekleyici rol üstlenir; yani, duyguların pozitif kullanımının yüksek olduğu bir durumda yaratıcı örgüt iklimi çalışan sesliliğini daha fazla etkiler.

\section{ARAŞTIRMA YÖNTEMI}

\subsection{Araştırmanın Amacı, Örneklem ve Ölçekler}

$\mathrm{Bu}$ çalışma yaratıcı örgüt ikliminin çalışan sesliliğine etkisinde duygusal zekânın moderatör rolünü tespit etmeyi amaçlamaktadır. Bu amaçla Bursa'nın İnegöl ilçesinde mobilya sektöründe faaliyette bulunan bir işletmeden anket yöntemiyle veri toplanmıştır. Araştırma tek bir işletme üzerinde gerçekleştirilen kesitsel bir çalışma niteliğindedir. İşletmede toplam çalışan sayısı 150 kişidir. Araştırmanın anakütlesini de bu 150 çalışan oluşturmaktadır. 150 kişilik bir anakütleden seçilecek örneklemin anakütleyi temsil edebilmesi için (\%95 güven düzeyinde \%5'lik bir hata payı ile) en az 108 kişi olması gerekmektedir (Krejcie ve Morgan, 1970). Bu örneklem sayısına ulaşmak için ankete gönüllü olarak katılmak isteyen 116 çalışana anket dağıtılmış ve dönen anketlerin hiçbirinde veri kayıpları olmaması sebebiyle hepsi değerlendirme kapsamına alınmıştır.

Araştırmada kullanılan ankette, demografik sorular ve değişkenleri ölçmeye ilişkin ifadeler bulunmaktadır. Demografik sorular katılımcıların cinsiyetlerini, medeni durumlarını, yaşlarını, eğitim durumlarını ve işletmede kaç yıldır çalıştıklarını belirlemeye yönelik beş sorudan oluşmaktadır. Araştırmaya katılan çalışanların demografik sorulara vermiş oldukları yanıtlara bakıldığında katılımcıların \%71.6'sını erkeklerin, \%53.4'ünü evli çalışanların, \%56.9'unu 26 yaş ile 35 yaş arasında bulunanların, 51.7'sini lise mezunlarının ve 57.8'ini 1 yıl ile 5 yıl arasında bir süredir işletmede görev yapanların oluşturduğu saptanmıştır.

Ankette araştırma değişkenlerini ölçen ifadeler 5'li Likert (1-Kesinlikle Katılmıyorum, 5Kesinlikle Katılıyorum) şeklinde tasarlanmıştır. Ayrıca değişkenleri ölçmeye ilişskin ifadeler daha önce geçerliliği ve güvenilirliği kanıtlanmış ölçeklerden elde edilmiştir. Araştırmada çalışanların yaratıcı örgüt iklimi algılarını ölçmek için Ekvall (1996) tarafından geliştirilen ve Sundgren vd. (2005) çalışmasında kullanılan yaratıcı örgüt iklimi ölçeğinden yararlanılmıştır. Ölçeğin Türkçe güvenilirliğini ölçen çalışmalardan birini Gürkan ve Koçoğlu (2014) yapmış ve çalışmada iki ayrı örneklemden elde ettikleri veriler sonucunda yaratıcı örgüt iklimi ölçeğinin iki örneklem için güvenilirlik katsayılarını 0.71 ve 0.96 olarak belirlemişlerdir. 
Başka bir ifade ile araştırmacılar ölçeğin Türkçe açısından da güvenilir olduğunu tespit etmişlerdir. Çalışanların duygusal zekâlarını ölçmek için Schutte ve arkadaşlarının (1998) geliştirdiği ve Chan (2006)'in çalışmasında 12 madde olarak kullanılan duygusal zekâ ölçeğinden yararlanılmıştır. Ölçek, duygusal değerlendirme (emotional appraisal), pozitif duygusal yönetim (positive regulation), empatik duyarlılık (empathic sensitivity) ve duyguların pozitif kullanımı (positive utilization) olmak üzere dört alt boyuttan oluşmaktadır. Ayrıca her boyut 3'er soru ile ölçülmektedir. Ayrıca Aslan ve Özata (2008) yapmış oldukları çalışmada duygusal zekâ ölçeğinin Türkçe açısından da güvenilir olduğunu tespit etmişlerdir. Aslan ve Özata'nın ölçeğe ilişkin ulaştıkları güvenilirlik katsayıları duygusal değerlendirme için 0.87 , pozitif duygusal yönetim için 0.83 , empatik duyarlılık için 0.88 ve duyguların pozitif kullanımı için 0.85 'dir. Çalışan sesliliğini ölçmek için ise Van Dyne ve LePine (1998) tarafından geliştirilen tek boyutlu 6 soruluk ölçek kullanılmıştır. Ölçeğin Türkçe uyarlamasını Çetin ve Çakmakçı (2012) gerçekleştirmiş ve araştırmacılar ölçeğin güvenilirlik katsayısını 0.87 olarak belirlemişlerdir.

\subsection{Bulgular}

\subsection{1. Ölçeklere İlişkin Faktör Analizi ve Güvenilirlik Analizi Bulguları}

Araştırmada ilk olarak ölçeklere doğrulayıcı faktör analizi uygulanmıştır. Böylece ölçeklerin yapı geçerliliği belirlenmeye çalışılmıştır. Doğrulayıcı faktör analizinde, maddelerin standardize edilmiş katsayılarının 0.40 'ın altında olmaması dikkate alınarak analizler değerlendirilmiştir. Dört alt boyuttan oluşan duygusal zekâ ölçeğine uygulanan doğrulayıcı faktör analizi sonucunda ölçek maddelerinin standardize edilmiş katsayılarının 0.40 değerinin üzerinde olduğu başka bir ifade ile gerekli koşulu sağladığı tespit edilmiştir. Bulgular ise Şekil 1'de sunulmuştur. 


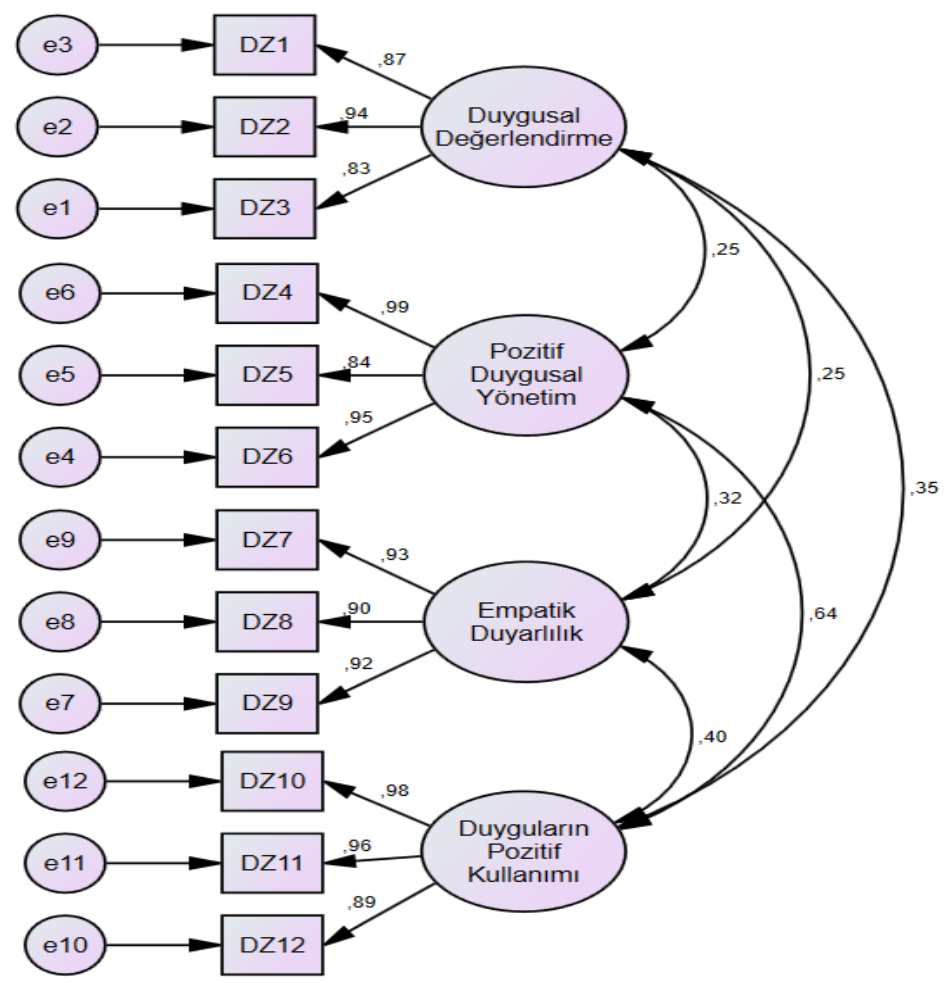

Şekil 1. Duygusal Zekâ Ölçeğine İlişkin Doğrulayıcı Faktör Analizi

Daha sonra duygusal zekâ ölçeğinin model uyum değerleri incelenmiş ve bulgular modelin uyumuna ilişkin referans değerleri ile birlikte Tablo 1'de sunulmuştur.

Tablo 1. Duygusal Zekâ Ölçeğinin Uyum İndekslerine İliş̧kin Değerler

\begin{tabular}{lll}
\hline İndeksler & Referans Değeri & Ölçüm Model \\
\hline CMIN/DF & $0<\chi^{2 / s d} \leq 5$ & 1.716 \\
\hline RMR & $\leq .08$ & .038 \\
\hline CFI & $\geq .90$ & .977 \\
\hline IFI & $\geq .90$ & .977 \\
\hline TLI & $\geq .90$ & .967 \\
\hline RMSEA & $<.05-\leq .10$ & .079 \\
\hline
\end{tabular}

Tablo 1'e bakıldığında duygusal zekâ ölçeğinin model ölçüm değerlerinin referans değerlerinden daha yüksek olduğu başka bir ifade ile gerekli ölçütleri sağladığ1 görülmektedir. Bu sonuca göre duygusal zekâ ölçeğinin dört boyutlu yapısının doğrulandığı belirtilebilir. Araştırmada daha sonra tek boyutlu çalışan sesliliği ölçeğine doğrulayıcı faktör analizi yapılmış ve bu ölçek maddelerinin de standardize edilmiş katsayılarının 0.40'ın üzerinde olduğu sonucuna ulaşılmıştır. Uyum değerlerine bakıldığında ise bazı değerlerin referans değerlerinin altında olduğu belirlenmiştir. Ancak SES2 ile SES5 ve SES4 ile SES6 
maddeleri arasında modifikasyon yapıldığı takdirde ölçeğin gerekli ölçütleri sağlayacağ1 anlaşılmıştır. Bundan dolayı ilgili maddeler arasında modifikasyon yapılmış ve ölçeğin modifikasyon sonrası standardize katsayıları Şekil 2'de gösterilmiştir.

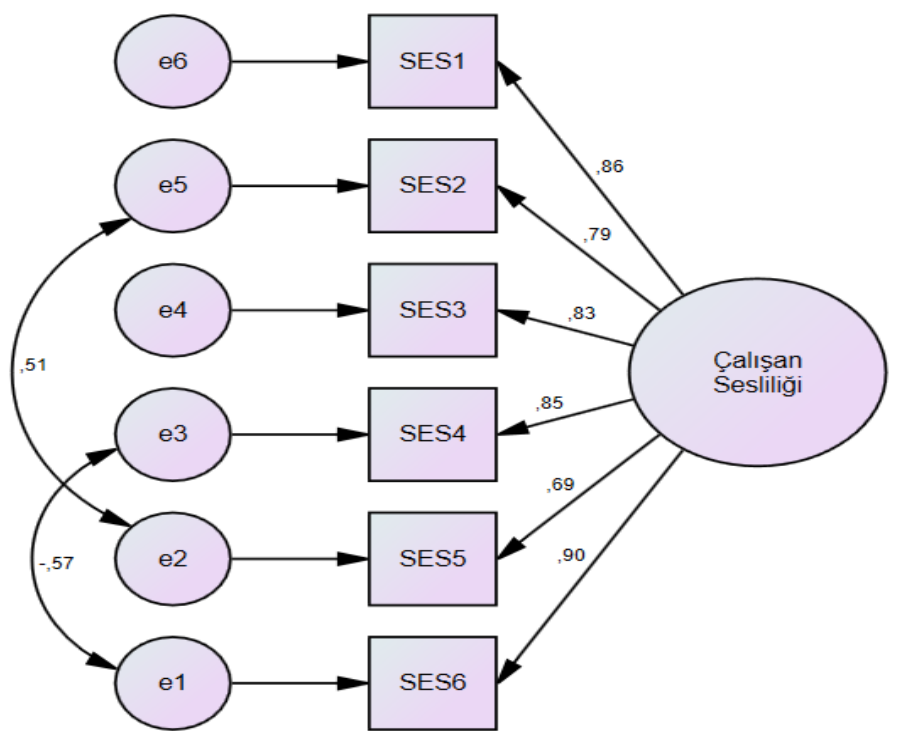

Şekil 2. Çalışan Sesliliği Ölçeğine İlişsin Doğrulayıcı Faktör Analizi

Daha sonra çalışan sesliliği ölçeğinin modifikasyon sonrası elde ettiği model uyum değerlerine bakılmış ve sonuçlar referans değerleri ile birlikte Tablo 2'de verilmiştir.

Tablo 2. Çalışan Sesliliği Ölçeğinin Uyum İndekslerine İlişkin Değerler

\begin{tabular}{lll}
\hline İndeksler & Referans Değeri & Ölçüm Model \\
\hline CMIN/DF & $0<\chi 2 / \mathrm{sd} \leq 5$ & 1.573 \\
\hline RMR & $\leq .08$ & .021 \\
\hline CFI & $\geq .90$ & .992 \\
\hline IFI & $\geq .90$ & .993 \\
\hline TLI & $\geq .90$ & .984 \\
\hline RMSEA & $<.05-\leq .10$ & .071 \\
\hline
\end{tabular}

Çalışan sesliliği ölçeğinin de tek boyutlu yapı geçerliliğinin doğrulandığı Tablo 2'den izlenmektedir. Araştırmada bu bulgulardan sonra yaratıcı örgüt iklimi ölçeğine doğrulayıcı faktör analizi uygulanmıştır. Analiz sonucunda ölçeğin standardize edilmiş katsayılarının gerekli koşulu sağladığ 1 ancak model uyum değerlerinin referans değerlerinden saptığ belirlenmiştir. Bununla birlikte YOR1 ile YOR6 ve YOR5 ile YOR6 maddeleri arasında modifikasyon yapıldığı takdirde ölçeğin uyum değerlerinin iyileşeceği tespit edilmiştir. Bu nedenle ilgili maddeler arasında modifikasyon gerçekleştirilmiş ve modifikasyon sonrası ölçeğin standardize katsayıları Şekil 3'de gösterilmiştir. 


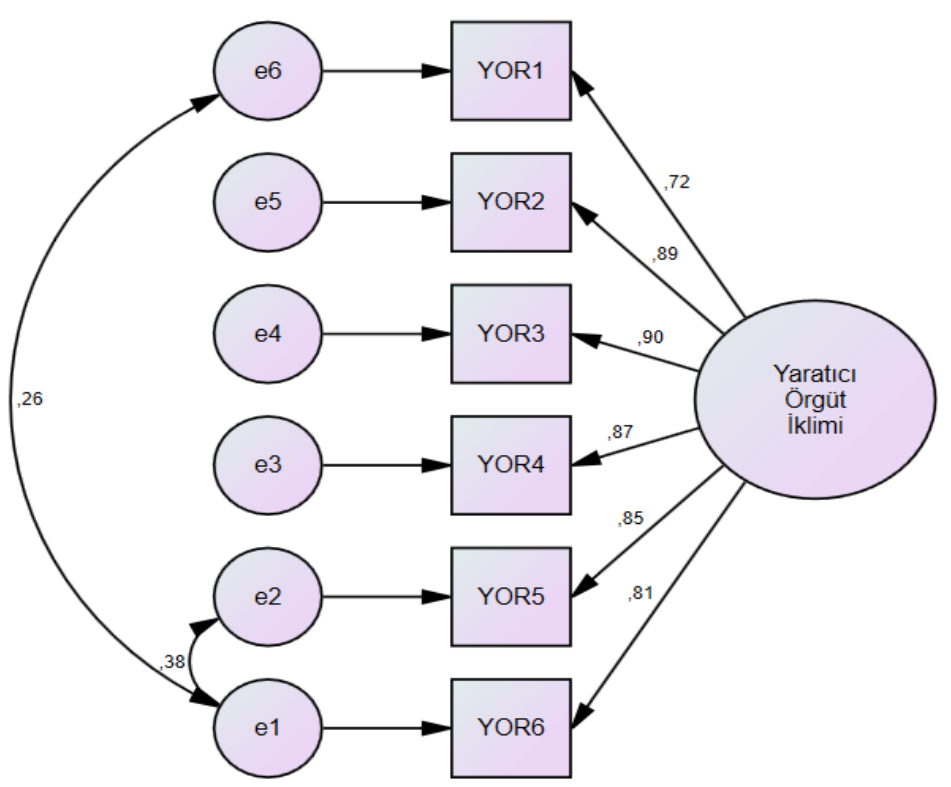

Şekil 3. Yaratıcı Örgüt İklimi Ölçeğine İlişkin Doğrulayıcı Faktör Analizi

Daha sonra yaratıcı örgüt iklimi ölçeğinin modifikasyon sonrası elde ettiği model uyum değerlerine bakılmış ve sonuçlar referans değerleri ile birlikte Tablo 3'de gösterilmiştir.

Tablo 3. Yaratıcı Örgüt İklimi Ölçeğinin Uyum İndekslerine İlişkin Değerler

\begin{tabular}{lll}
\hline İndeksler & Referans Değeri & Ölçüm Model \\
\hline CMIN/DF & $0<\chi^{2 / \mathrm{sd} \leq 5}$ & 1.473 \\
\hline RMR & $\leq .08$ & .014 \\
\hline CFI & $\geq .90$ & .994 \\
\hline IFI & $\geq .90$ & .994 \\
\hline TLI & $\geq .90$ & .988 \\
\hline RMSEA & $<.05-\leq .10$ & .064 \\
\hline
\end{tabular}

Tablo 3 yaratıcı örgüt iklimi ölçeğinin modifikasyon sonrası model uyum değerlerinin gerekli ölçütleri sağladığını göstermektedir. Bu bulgulara göre yaratıcı örgüt iklimi ölçeğinin de tek boyutlu yapı geçerliliğinin doğrulandığı belirtilebilir.

Ölçeklerin yapısına ilişkin değerlendirme, doğrulayıcı faktör analizi ile gerçekleştirildikten sonra ölçeklerin güvenilirliklerini sınayabilmek için ölçeklerin içsel tutarlılığını gösteren cronbach alpha değerleri incelenmiştir. Güvenilirlik analizinde ölçeklerin güvenilir olarak kabul edilebilmesi için cronbach alfa katsayısının 0.70 ve üzerinde olması beklenmektedir (Morgan, Leech, Gloeckner ve Barrett, 2004: 122). Gerçekleştirilen analizler ile duygusal zekâ (.895), çalışan sesliliği (.927) ve yaratıcı örgüt iklimi (.939) ölçeklerinin güvenilir olduğu belirlenmiştir. Ayrıca duygusal zekânın alt boyutları içerisinde bulunan duygusal 
değerlendirmenin (.905), pozitif duygusal yönetimin (.945), empatik duyarlılı̆̆ın (.938) ve duyguların pozitif kullanımının da (.958) güvenilir olduğu tespit edilmiştir.

\subsubsection{Araştırma Hipotezlerinin Testi}

Araştırmada ilk olarak korelasyon analizi yapılarak değişkenler arasındaki ilişkinin yönü ve gücü belirlenmiştir. Daha sonra da hiyerarşik regresyon analizi ile hipotezler sınanmıştır. Korelasyon analizine ilişkin bulgular Tablo 4'de gösterilmiştir.

Tablo 4. Değișkenlere İlișkin Korelasyon Bulguları

\begin{tabular}{|c|c|c|c|c|c|c|c|c|}
\hline Değişkenler & $\bar{\pi}$ & SS & 1 & 2 & 3 & 4 & 5 & 6 \\
\hline 1- Çalışan Sesliliği & 4.041 & .792 & 1 & & & & & \\
\hline 2- Yaratıcı Örgüt İklimi & 4.280 & .785 & $.802^{* *}$ & 1 & & & & \\
\hline 3- Duygusal Zekâ & 4.133 & .595 & $.794^{* *}$ & $.735^{* * *}$ & 1 & & & \\
\hline $\begin{array}{l}\text { 4- Duygusal } \\
\text { Değerlendirme }\end{array}$ & 3.913 & .841 & $.411^{* *}$ & $.396^{* *}$ & $.641^{* *}$ & 1 & & \\
\hline $\begin{array}{l}\text { 5- Pozitif Duygusal } \\
\text { Yönetim }\end{array}$ & 4.232 & .826 & $.680^{* *}$ & $.610^{* * *}$ & $.759^{* * *}$ & $.235^{* *}$ & 1 & \\
\hline 6- Empatik Duyarl111k & 4.112 & .835 & $.510^{* *}$ & $.573^{* *}$ & $.687^{* * *}$ & $.259^{* * *}$ & $.333^{* *}$ & 1 \\
\hline $\begin{array}{l}\text { 7- Duyguların Pozitif } \\
\text { Kullanımı }\end{array}$ & 4.275 & .787 & $.707^{* *}$ & $.551^{* *}$ & $.814^{* * *}$ & $.350^{* * *}$ & $.641^{* * *}$ & $.392^{* *}$ \\
\hline
\end{tabular}

$* \mathrm{p}<0.05 \quad * * \mathrm{p}<0.01$

Tablo 4'e bakıldığında yaratıcı örgüt iklimi ile çalışan sesliliği arasında pozitif yönlü (.740), yaratıcı örgüt iklimi ile duygusal zekâ arasında pozitif yönlü (.802), benzer şekilde duygusal zekâ ile çalışan sesliliği arasında da pozitif yönlü (.794) ve anlamlı ilişkiler olduğu tablodan izlenmektedir. Ayrıca duygusal zekânın alt boyutlarının da hem çalışan sesliliği ile hem de yaratıcı örgüt iklimi ile pozitif yönlü ilişkilere sahip olduğu tabloda görülmektedir.

Korelasyon analizinden sonra değişkenler arasındaki neden sonuç ilişkilerini tespit etmek ve duygusal zekânın destekleyici/moderatör rolünü ortaya koyabilmek için hiyerarşik regresyon analizi yapılmıştır. Hiyerarşik regresyon analizinde Aiken West ve Reno (1991)'un önerdiği şekilde yordayıcılar merkezileştirilerek elde edilen yeni skorların çarpımı ile etkileşim değişkeni oluşturulmuş ve moderatör etki bu yolla değerlendirilmeye çalışılmıştır.

Araştırmanın hipotezlerini sınamak amacıyla hiyerarşik regresyon analizinde ilk olarak çalışan sesliliğinin bağımlı değişken ve demografik faktörlerin kontrol değişkeni olarak değerlendirildiği bir model oluşturulmuştur. Daha sonra modele 2. Adımda yaratıcı örgüt iklimi ve duygusal zekâ bağımsız değişkenler olarak eklenmiştir. 3. ve son adımda ise duygusal zekânın destekleyici rolünü ortaya çıkarabilmek amacıyla yaratıcı örgüt iklimi ile duygusal zekânın çarpımı sonucu elde edilen moderatör değişken modele dâhil edilmiş ve sonuçlar Tablo 5'de gösterilmiştir. 
Tablo 5. Hiyerarşik Regresyon Analizi Bulguları

\begin{tabular}{|c|c|c|c|c|c|c|}
\hline \multirow[t]{3}{*}{ Değişkenler } & \multicolumn{6}{|c|}{ Bağımlı Değişken: Çalışan Sesliliği } \\
\hline & \multicolumn{2}{|c|}{ Model 1} & \multicolumn{2}{|c|}{ Model 2} & \multicolumn{2}{|c|}{ Model 3} \\
\hline & B & $\mathrm{T}$ & $\mathrm{B}$ & $\mathrm{T}$ & $\mathrm{B}$ & $\mathrm{T}$ \\
\hline Cinsiyet & -.494 & $-3.092 * *$ & -.099 & -1.103 & -.053 & -.609 \\
\hline Medeni Durum & .266 & $2.166 *$ & .120 & $1.786 *$ & .098 & 1.519 \\
\hline Yaş & .295 & 2.424* & .072 & 1.070 & .048 & .746 \\
\hline Eğitim Durumu & .005 & .059 & -.003 & -.055 & -.025 & -.569 \\
\hline Çalışma Süresi & .120 & 1.063 & .141 & $2.295 *$ & .120 & $2.037 *$ \\
\hline $\begin{array}{c}\text { Yaratıcı Örgüt İklimi } \\
\text { (YOR) }\end{array}$ & - & - & .462 & $6.554 * * *$ & .586 & $7.689 * * *$ \\
\hline Duygusal Zekâ (DZ) & - & - & .558 & $5.992 * * *$ & .756 & $7.149 * * *$ \\
\hline YOR*DZ (Moderator) & - & - & - & - &. $\mathbf{0 8 0}$ & $3.445 * * *$ \\
\hline $\mathbf{R}^{2}$ & \multicolumn{2}{|c|}{.173} & \multicolumn{2}{|c|}{.762} & \multicolumn{2}{|c|}{.786} \\
\hline Düzeltmiş $\mathbf{R}^{2}$ & \multicolumn{2}{|c|}{.135} & \multicolumn{2}{|c|}{.746} & \multicolumn{2}{|c|}{.770} \\
\hline $\mathbf{F}$ & \multicolumn{2}{|c|}{$4.598 * * *$} & \multicolumn{2}{|c|}{$49.378 * * *$} & \multicolumn{2}{|c|}{ 49.039*** } \\
\hline$\Delta \mathbf{R}^{2}$ & \multicolumn{2}{|c|}{$.173 * * *$} & \multicolumn{2}{|c|}{$.589 * * *$} & \multicolumn{2}{|c|}{$.024 * * *$} \\
\hline
\end{tabular}

Tablo 5'deki sonuçlardan ikinci modele bakıldığında yaratıcı örgüt ikliminin (.462) ve duygusal zekânın (.558) çalışan sesliliği üzerinde anlamlı $(\mathrm{p}<0.001)$ etkiye sahip olduğu anlaşılmakta ve modelin açıklama gücünün \%74.6 olduğu görülmektedir. Bu sonuçlara göre H1 (Yaratıcı örgüt iklimi çalışanların seslilik davranışını pozitif yönde etkiler) hipotezinin kabul edildiği belirtilebilir. Düzenleyici değişkenin (yaratıcı örgüt iklimi x duygusal zekâ) dâhil edildiği üçüncü modele bakıldığında ise modelin açıklama gücünün \%77'ye yükseldiği ve bu artışın istatistiksel olarak anlamlı olduğu $(F=49.039$ ve $p<0.001)$ anlaşılmaktadır. $\mathrm{Bu}$ bulgular yaratıcı örgüt iklimi ile çalışan sesliliği arasındaki ilişkide duygusal zekânın düzenleyici etkiye sahip olduğunu göstermektedir. Ancak modelin açıklama gücündeki değişimin daha iyi yorumlanabilmesi için moderatör değişkeninin yüksek düzey ve düşük düzey şeklinde olmak üzere farklı düzeylerdeki durumlarını gösteren grafiğinin çizilmesi gerekmektedir (Aiken, West ve Reno, 1991). Bu nedenle yaratıcı örgüt iklimi ile çalışan sesliliği arasındaki ilişkide duygusal zekânın farklı düzeylerini gösteren düzenleyici etki grafiği oluşturulmuş ve grafik Şekil 4'de gösterilmiştir. 


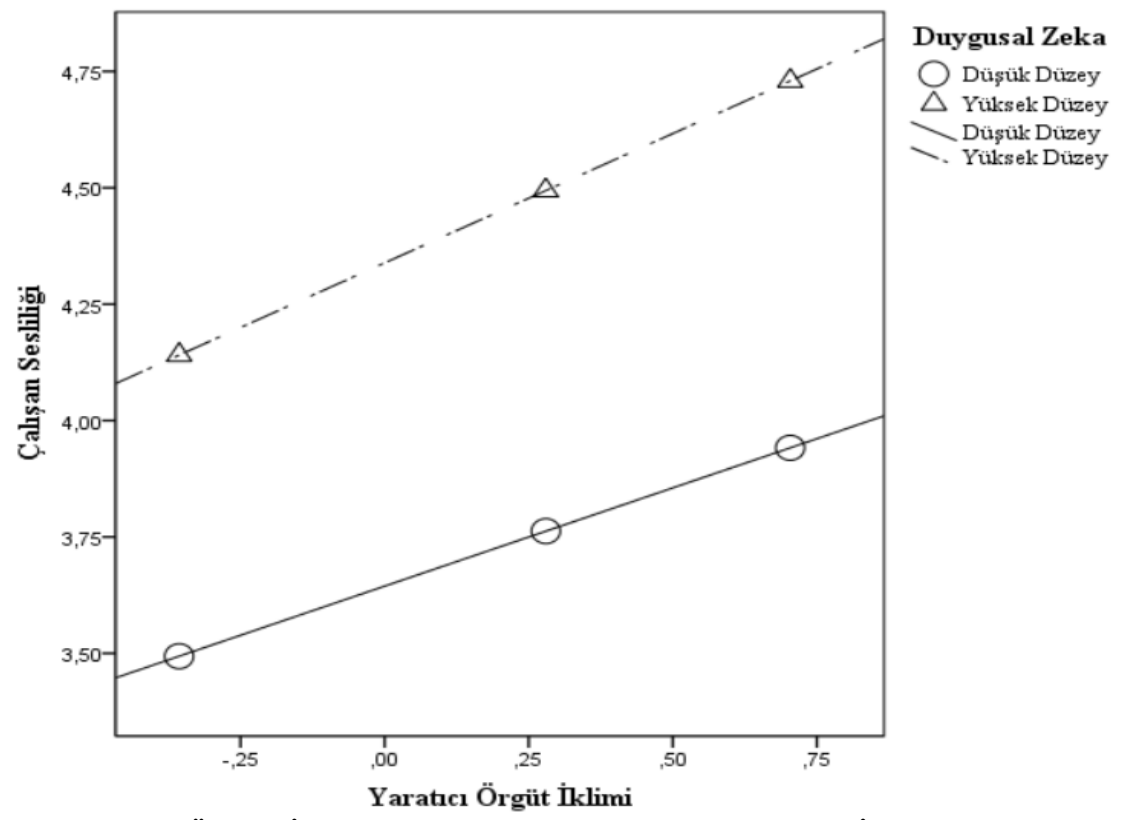

Şekil 4. Yaratıcı Örgüt İklimi ile Çalışan Sesliliği Arasındaki İlişkide Duygusal Zekânın Moderatör Rolü

Şekil 4'e bakıldığında yaratıcı örgüt ikliminin çalışan sesliliği üzerindeki etkisinin en yüksek olduğu noktanın duygusal zekânın en yüksek olduğu nokta olduğu anlaşılmaktadır. Ayrıca şekil, yaratıcı örgüt ikliminin çalışan sesliliği üzerindeki etkisinde duygusal zekânın yüksek olduğu düzeyi gösteren çizginin eğiminin düşük düzeyine göre daha dik olduğunu göstermektedir. Bu bulgu yaratıcı örgüt iklimi algılayan çalışanların duygusal zekâları da yüksek olduğunda duygusal zekâları düşük olanlara göre daha çok seslilik davranışına yöneldiklerini ifade etmektedir. Tablo 5'deki ve Şekil 4'deki sonuçlara bağlı olarak H2 (Yaratıcı örgüt ikliminin çalışan sesliliği davranışına etkisinde duygusal zekâ destekleyici rol üstlenir; yani, duygusal zekânın yüksek olduğu bir durumda yaratıcı örgüt iklimi çalışan sesliliğini daha fazla etkiler) hipotezinin de kabul edildiği belirtilebilir.

Daha sonra yaratıcı örgüt ikliminin çalışan sesliliği üzerindeki etkisinde duygusal zekânın hangi boyutunun veya boyutlarının moderatör etki oluşturduğu araştırılmış ve hiyerarşik regresyon analizleri sonucunda duygusal zekâ boyutlarından sadece duyguların pozitif kullanımının yaratıcı örgüt iklimi ile çalışan sesliliği arasındaki ilişkide moderatör role sahip olduğu sonucuna ulaşılmıştır. Bu ulaşılan bulgulara bağlı olarak H2a, H2b ve H2c hipotezleri reddedilmiştir. Duyguların pozitif kullanımına ilişkin moderatör etkinin değerlendirildiği hiyerarşik regresyon analizi sonuçları ise Tablo 6'da gösterilmiştir. 
Tablo 6. Duyguların Pozitif Kullanımına İlișkin Moderatör Etki Bulguları

\begin{tabular}{|c|c|c|c|c|c|c|}
\hline \multirow[t]{3}{*}{ Değişkenler } & \multicolumn{6}{|c|}{ Bağımlı Değişken: Çalışan Sesliliği } \\
\hline & \multicolumn{2}{|c|}{ Model 1} & \multicolumn{2}{|c|}{ Model 2} & \multicolumn{2}{|c|}{ Model 3} \\
\hline & B & $\mathrm{T}$ & B & $\mathrm{T}$ & B & $\mathrm{T}$ \\
\hline Cinsiyet & -.494 & $-3.092 * *$ & -.067 & -.754 & -.042 & -.483 \\
\hline Medeni Durum & .266 & 2.166* & .094 & 1.429 & .087 & 1.333 \\
\hline Yaş & .295 & $2.424 *$ & .021 & .310 & .003 & .044 \\
\hline Eğitim Durumu & .005 & .059 & -.007 & -.159 & -.026 & -.575 \\
\hline Çalışma Süresi & .120 & 1.063 & .174 & $2.882 * *$ & .169 & $2.859 * *$ \\
\hline $\begin{array}{c}\text { Yaratıcı Örgüt İklimi } \\
\text { (YOR) }\end{array}$ & - & - & .581 & $10.302 * * *$ & .664 & $9.995 * * *$ \\
\hline $\begin{array}{l}\text { Duyguların Pozitif } \\
\text { Kullanımı (DPK) }\end{array}$ & - & - & .368 & $6.454 * * *$ & .416 & $6.951 * * *$ \\
\hline YOR*DPK (Moderator) & - & - & - & - & .054 & $2.262 * *$ \\
\hline $\mathbf{R}^{2}$ & \multicolumn{2}{|c|}{.173} & \multicolumn{2}{|c|}{.771} & \multicolumn{2}{|c|}{.782} \\
\hline Düzeltmiş $\mathbf{R}^{2}$ & \multicolumn{2}{|c|}{.135} & \multicolumn{2}{|c|}{.756} & \multicolumn{2}{|c|}{.765} \\
\hline $\mathbf{F}$ & \multicolumn{2}{|c|}{$4.598 * * *$} & \multicolumn{2}{|c|}{$51.971 * * *$} & \multicolumn{2}{|c|}{$47.848 * * *$} \\
\hline$\Delta \mathbf{R}^{2}$ & \multicolumn{2}{|c|}{$.173 * * *$} & \multicolumn{2}{|c|}{$.598 * * *$} & \multicolumn{2}{|c|}{$.010 * * *$} \\
\hline
\end{tabular}

Tablo 6'da ikinci modele ilişkin bulgular incelendiğinde yaratıcı örgüt ikliminin (.581) ve duyguların pozitif kullanımının ( .368$)$ çalışan sesliliği üzerinde anlamlı $(\mathrm{p}<0.001)$ etkiye sahip olduğu ve modelin açıklama gücünün \%75.6 olduğu anlaşılmaktadır. Düzenleyici değişkenin (yaratıcı örgüt iklimi x duyguların pozitif kullanımı) dâhil edildiği üçüncü modele bakıldığında ise modelin açıklama gücünün \%76.5'e yükseldiği ve bu artışın istatistiksel olarak anlamlı olduğu $(\mathrm{F}=47.848$ ve $\mathrm{p}<0.001)$ anlaşılmaktadır. Bu bulgular yaratıcı örgüt iklimi ile çalışan sesliliği arasındaki ilişkide duygusal zekâ boyutlarından duyguların pozitif kullanımının düzenleyici etkiye sahip olduğunu göstermektedir. Ayrıca yaratıcı örgüt iklimi ile çalışan sesliliği arasındaki ilişkide duyguların pozitif kullanımının moderatör etkisini daha iyi anlayabilmek adına duyguların pozitif kullanımının düşük ve yüksek düzeylerini gösteren eğim grafiği (simple slope) oluşturulmuş ve grafik Şekil 5'de gösterilmiştir. 


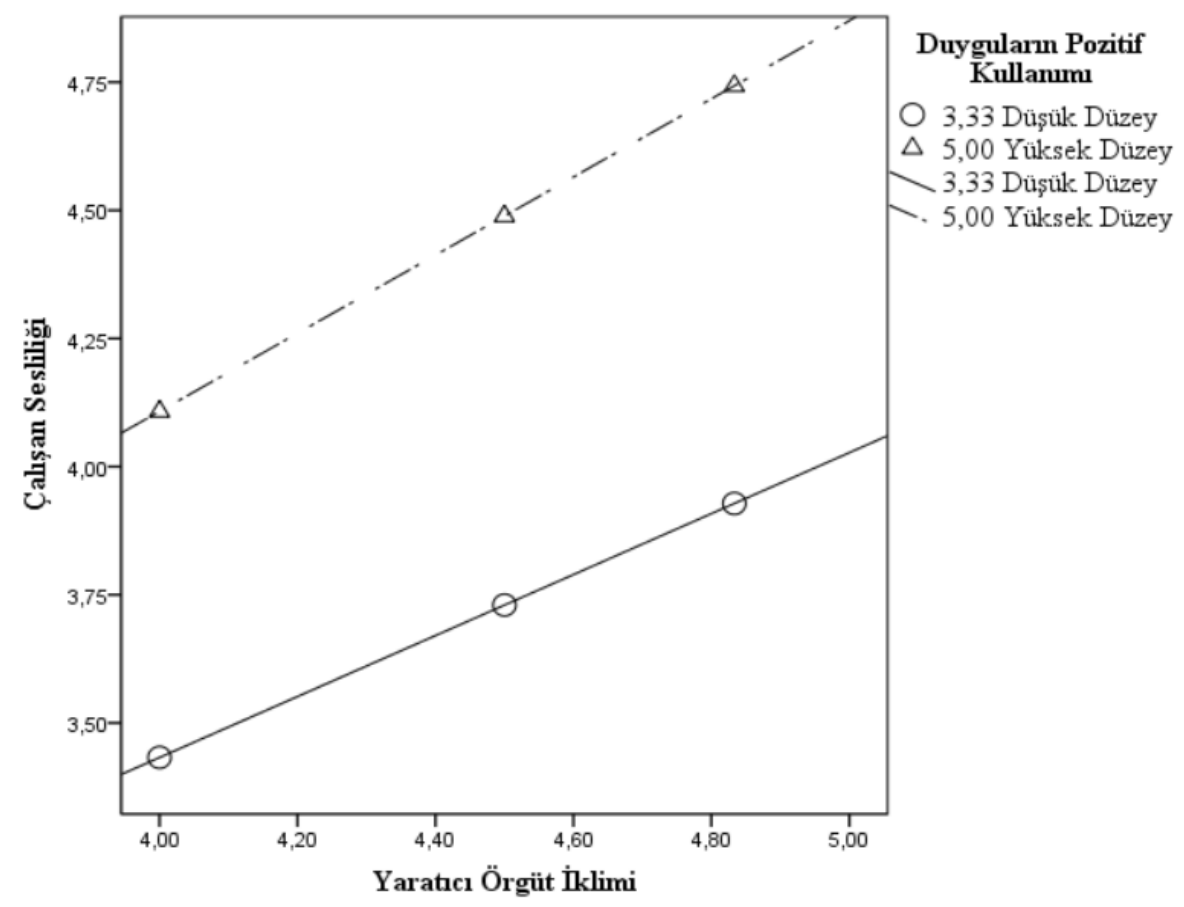

Şekil 5. Yaratıcı Örgüt İklimi ile Çalışan Sesliliği Arasındaki İlişkide Duyguların Pozitif Kullanımının Moderatör Rolü

Şekil 5 ile duyguların pozitif kullanımının moderatör etkisi incelendiğinde yaratıcı örgüt ikliminin çalışan sesliliği üzerindeki etkisinin duyguların pozitif kullanımının en yüksek olduğu noktada en yüksek düzeye ulaştığı görülmektedir. Ayrıca duyguların pozitif kullanımının düşük olduğu durumda yaratıcı örgüt ikliminin çalışan sesliliği üzerindeki etkisinin daha düşük düzeyde kaldığı anlaşılmaktadır. Bu açıdan, yaratıcı örgüt ikliminin çalışan sesliliği üzerindeki etkisinde duyguların pozitif kullanımının destekleyici role sahip olduğu söylenebilir. Başka bir ifade ile Tablo 6'daki ve Şekil 5'deki sonuçlara bağlı olarak $\mathrm{H} 2 \mathrm{~d}$ (Yaratıcı örgüt ikliminin çalışan sesliliği davranışına etkisinde duyguların pozitif kullanımı destekleyici rol üstlenir; yani, duyguların pozitif kullanımının yüksek olduğu bir durumda yaratıcı örgüt iklimi çalışan sesliliğini daha fazla etkiler) hipotezinin de kabul edildiği belirtilebilir.

\section{SONUÇ VE DEĞERLENDİRME}

Örgütlerin geleceği açısından çalışanlar önemli bir yere sahiptirler. Çünkü çalışanlar, örgüt yararına olumlu davranışlarda bulunduklarında örgütlerin performansını arttırmakta böylece örgütlerin diğer örgütler karşısında daha güçlü ve başarılı olmalarını sağlayabilmektedirler. $\mathrm{Bu}$ nedenle çalışanların olumlu davranışlarını ortaya çıkarabilecek faktörlerin neler olabileceğinin araştırılması gerekmektedir. Çalışan sesliliği de çalışanların örgüt yararına fikirlerini beyan ederek örgütün gelişmesine katkı sağladıkları olumlu davranışlardan biridir. Ayrıca çalışan sesliliği; örgütsel etkililiği (Jha vd., 2019; Ruck, Welch ve Menara, 2017) örgütsel bağlılığı (Prasadika ve Nishanthi, 2018), işe bağlanmayı (Jha vd., 2019) ve iş tatminini (Alfayad ve Arif, 2017) arttırmak, tükenmeyi (Thohiroh ve Satrya, 2019) ve işten 
ayrılma niyetini (Lam vd., 2016) azaltmak gibi örgütler açısından birçok olumlu sonucu da beraberinde getirmektedir. $\mathrm{Bu}$ olumlu sonuçlarından dolayı çalışan sesliliği, örgütlerin geliştirmesi ve ortaya çıkarması gereken bir davranış olarak değerlendirilmektedir. Bu öneminden dolayı araştırmada çalışan sesliliğine hangi faktörlerin etki oluşturabileceği araştırılmış ve "yaratıcı örgüt iklimi algısı çalışan sesliliği davranışının belirleyicisi midir?" ile "yaratıcı örgüt iklimi algısının çalışan sesliliği davranışı üzerindeki etkisinde duygusal zekâ destekleyici role sahip midir?” sorularına yanıt aranmıştır.

Araştırma sonucunda ilk olarak çalışanların yaratıcı örgüt iklimi algılarının seslilik davranışlarını pozitif yönde ve anlamlı olarak etkilediği belirlenmiştir. Başka bir ifade ile yaratıcı örgüt iklimi algısının çalışan sesliliğinin bir belirleyicisi olduğu tespit edilmiştir. Literatürdeki çalışmalar, yaratıcı örgüt iklimi ve seslilik davranışlarını olumlu etkileyebileceği öngörüsünü desteklemekle birlikte (Lundmark ve Björkman, 2011), bu sonucu doğrudan bulgulayan bir araştırma literatürde mevcut değildir. Bu sonuca göre farklı fikirlerin, düşüncelerin kolayca söylenebildiği, sorunlara çalışanların kendi çözümlerini üretebildiği ve yaratıcılığın desteklendiği bir örgüt ortamının algılanması durumunda kişilerin örgütün mevcut durumunu iyileştirmek için fikirlerini açıklayarak yapıcı önerilerde bulunabileceği söylenebilir. İkinci olarak ulaşılan bulgu ise yaratıcı örgüt ikliminin çalışan sesliliği üzerindeki etkisinde duygusal zekânın destekleyici role sahip olduğu şeklinde olmuştur. $\mathrm{Bu}$ sonuç yaratıcı örgüt iklimi algılayan çalışanların aynı zamanda kendi duygularını ve başkalarının duygularını fark edebilme ve duygularını yönetebilme yetenekleri de yüksek olduğunda daha çok seslilik davranışında bulunabileceğini ifade etmektedir. Bu sonuçlar belirlendikten sonra duygusal zekâ boyutlarından hangisinin yaratıcı örgüt iklimi ile çalışan sesliliği arasındaki ilişkide destekleyici role sahip olduğu incelenmiş ve sadece duyguların pozitif kullanımının moderatör etkisinin anlamlı olduğu sonucuna ulaşılmıştır. Duygusal değerlendirmenin, pozitif duygusal yönetimin ve empatik duyarlılı̆̆ın ise moderatör etkilerinin anlamsız olduğu tespit edilmiştir.

Duyguların pozitif kullanımında birey olumlu ruh halindeyken yeni fikirler üretebildiğini, daha iyi problem çözebildiğini ve insanlar üzerinde iyi etki bırakabildiğini düşünmektedir. $\mathrm{Bu}$ anlamına bağlı olarak yaratıcı örgüt ikliminin çalışan sesliliği üzerindeki etkisinde duyguların pozitif kullanımının destekleyici rolünün anlamlı olması şaşırtıcı olmamıştır. Çünkü yaratıcı örgüt ikliminin olduğu bir örgütte çalışan yaratıcılığın ortaya çıkabilmesi için fikirlerin serbestçe söylenmesi gerektiğini algılamaktadır. Fikirlerini dile getirmenin kabul edildiği bir ortamda ise kişi bir de olumlu ruh haline sahipse başka bir ifade ile yeni fikirler üretebileceğini, daha iyi problem çözebileceğini ve insanlar üzerinde olumlu etki oluşturabileceğini düşünüyorsa daha çok seslilik davranışında bulunması olası gözükmektedir. Ulaşılan bulgu bu olası sonucu doğrulamıştır.

Literatüre bakıldığında ise yaratıcı örgüt ikliminin çalışan sesliliğine etkisini ve bu etki de duygusal zekânın destekleyici rolünün bulunup bulunmadığını araştıran bir çalışmaya rastlanılmamıştır. Bu nedenle araştırmada ulaşılan yaratıcı örgüt ikliminin çalışan sesliliği üzerinde pozitif yönlü ve anlamlı etkisi bulgusunun ve yaratıcı örgüt ikliminin çalışan sesliliği üzerindeki etkisinde duygusal zekânın destekleyici rolünün anlamlı olduğu bulgusunun ilk olduğu ve hem ulusal hem de uluslararası literatür için önemli olduğu söylenebilir. Çalışmanın literatüre sağlamış olduğu bu teorik katkının yanında bazı pratik katkılarından da bahsedilebilir. Araştırma, çalışanlarının seslilik davranışlarını arttırmayı isteyen örgütlere yaratıcı örgüt iklimine ve çalışanlarının duygusal zekâlarına özellikle 
duygusal zekâ boyutlarından duyguların pozitif kullanımına daha fazla dikkat etmesi gerektiğini göstermektedir. $\mathrm{Bu}$ nedenle örgütlerde yaratıcı örgüt ikliminin algılanmasını sağlayacak davranışların arttırılması gerekmektedir. Bu konuda öncelikle liderlere çok iş düşmektedir. Çünkü daha önce yapılan araştırmalar, yaratıcı örgüt ikliminin ortaya çıkmasında liderin etkisinin olduğunu ileri sürmektedir (Isaksen, 2017). Bu nedenle yöneticilere ve gelecekte yönetici olması planlanan kişilere yaratıcılık ile yeniliğin önemi konusunda ve yaratıcılıkla ilgili neler yapılabileceği konusunda uygulamaya dönük eğitimler verilmelidir. Ayrıca duygusal zekânın ne kadar önemli olduğu yine bu eğitimlerde ilgili kişilere aktarılmalıdır. Bunun yanında işe alım sürecinde çalışan adaylarına duygusal zekâlarını ölçmeye ilişkin testler uygulanmalı ve özellikle duyguların pozitif kullanımı boyutunun yüksek olduğu kişiler işe alımda öncelikli olarak tercih edilmelidir. Böylece örgütler çalışan sesliliği davranışının ortaya çıkabilmesi için bir nebze de olsa doğru adımları atmış olacaktır.

Bütün bu açıklamaların dışında her çalışmada olduğu gibi bu araştırmanın da kısıtları bulunmaktadır. Araştırmanın yalnızca tek bir işletmede yapılması, kesitsel bir çalışma olması ve çalışan sesliliği üzerinde sadece yaratıcı örgüt iklimi ile duygusal zekâ değişkenlerinin etkilerini belirlemeye çalışması araştırmanın kısıtlarını oluşturmaktadır. $\mathrm{Bu}$ kısıtlarından dolayı bundan sonra bu değişkenler üzerinde araştırma yapacak kişilere farklı örneklemler üzerinde araştırmalarını yapmaları önerilebilir. Çünkü bu araştırmada bulgular sadece araştırmanın yapıldığı işletmeye ilişkindir ve genellenememektedir. Ayrıca çalışan sesliliği üzerinde farklı değişkenlerin de etkisi olacağından bundan sonraki araştırmalarda bu modele liderlik, iş becerikliliği, kişilik, örgütsel güven gibi başka değişkenleri de ekleyerek araştırmayı genişletmeleri önerilebilir.

\section{KAYNAKÇA}

ACAR, F. (2002). "Duygusal Zekâ ve Liderlik", E.Ü. Sosyal Bilimler Enstitüsü Dergisi, (1), 53-68.

ADSIZ, E. (2016). "Yöneticilerin Duygusal Zekâ Düzeylerinin Karar Verme Stillerine Etkisini Belirlemeye Yönelik Bir Araştırma", Yüksek Lisans Tezi, Hitit Üniversitesi, Sosyal Bilimler Enstitüsü.

AHMAD, S. A., SElEIM, A., BONTIS, N., \& MOSTAPHA, N. (2017). "Emotional Intelligence and Career Outcomes: Evidence from Lebanese Banks", Knowledge and Process Management, 24(3), 161-169.

AIKEN, L. S., WEST, S. G., \& RENO, R. R. (1991). Multiple Regression: Testing and interpreting Interactions. Sage, Newbury Park.

ALFAYAD, Z., \& ARIF, L. S. M. (2017). "Employee Voice and Job Satisfaction: An Application of Herzberg's Two-factor Theory", International Review of Management and Marketing, 7(1), 150-156.

ALPARSLAN, A. M., \& KAYALAR, M. (2012). “Örgütsel Sessizlik: Sessizlik Davranışları ve Örgütsel ve Bireysel Etkileri”, Mehmet Akif Ersoy Üniversitesi Sosyal Bilimler Enstitüsü Dergisi, 4 (6), 136-147. 
AMABILE, T. M. (1988). A Model Of Creativity And Innovation In Organizations, In B.M. Staw \& L.L. Cummings (Eds.), Research In Organizational Behavior, Vol.10; 123 167. Greenwich, Ct: Jai Press.

AMABILE, T. M., CONTI, R., COON, H., LAZENBY, J., \& HERRON, M. (1996), "Assessing The Work Environment For Creativity", Academey Of Management Journal, 39(5), 1154-1184.

ARGYRIS, C., \& SCHÖN, D. (1978). Organizational Learning: A Theory Of Action Perspective, Addison-Wesley, MA.

ASLAN, Ş., \& ÖZATA, M. (2008). "Duygusal Zekâ ve Tükenmişlik Arasındaki İlişkilerin Araştırılması: Sağlık Çalışanları Örneği”. Erciyes Üniversitesi İktisadi ve İdari Bilimler Fakültesi Dergisi, (30), 77-97.

BAR-ON, R. (2005). The Bar-On Model of Emotional-Social Intelligence. In FernándezBerrocal Pand Extremera N (Guest Editors), Special Issue On Emotional Intelligence (Psicothema), 3.

BOTERO, C. I., \& VAN DYNE, L. (2009). "Employee Voice Behavior Interactive Effects of LMX and Power Distance in the United States and Colombia", Management Communication Quarterly, 23 (1), 84-104.

BOWEN F., \& BLACKMON, K. (2003). "Spirals of Silence: The Dynamic Effects of Diversity on Organizational Voice", Journal of Management Studies, 40 (6), 13931417.

BULUT, H., \& MEYDAN, C. H. (2018). "Liderlik Tarzlarının Çalışanların Ses Verme Davranışına Etkisi: Kamuda Bir Araştırma”, Ankara Üniversitesi SBF Dergisi, 73 (1), 223-244.

CARMELI, A. (2003). "The Relationship Between Emotional Intelligence and Work Attitudes, Behavior and Outcomes: An Examination Among Senior Managers", Journal of Managerial Psychology, 18(8), 788-813.

CHAN, D. W. (2004). "Perceived Emotional Intelligence and Self-efficacy Among Chinese Secondary School Teachers in Hong Kong”, Personality and Individual Differences, 36, 1781-1795.

CHAN, D. W. (2006). "Emotional Intelligence and Components of Burnout Among Chinese Secondary School Teachers in Hong Kong”, Teaching and Teacher Education, 22, 1042-1054.

CHEN, X. (2018). "Emotional Intelligence Effects on Constructive Voice and Destructive Voice: A Moderating Role of Inclusive Leadership", 2nd International Conference on Education, Management and Applied Social Science (EMASS)

CUMMINGS, A., \& OLDHAM, G. R. (1997). "Enhancing Creativity: Managing Work Contexts for the High Potential Employee", California Management Review, 40(1), 22-38.

ÇETİN, Ş., \& ÇAKMAKÇI, C. (2012). "Çalışan Sesliliği Ölçeğini Türkçe’ye Uyarlama Çalışması”, KHO Bilim Dergisi, 22(2), 1-19. 
ÇETINKAYA, Ö., \& ALPARSLAN, A. M. (2001). "Duygusal Zekânın İletişim Becerileri Üzerine Etkisi: Üniversite Öğrencileri Üzerinde Bir Araştırma”, İktisadi ve İdari Bilimler Fakültesi Dergisi, 16(1), 366.

DETERT, J. R., \& BURRIS, E. R. (2007). "Leadership Behavior and Employee Voice: Is The Door Really Open?", Academy of Management Journal, 50, 869-884.

DUAN, J., LI, C., XU, Y., \& WU, C. H. (2017). “Transformational Leadership and Employee Voice Behavior: A Pygmalion Mechanism”, Journal of Organizational Behavior, 38(5), 650-670.

DUBINA I. N. (2013). Measuring Organizational Climate for Creativity and Innovation. In: Carayannis E.G. (eds) Encyclopedia of Creativity, Invention, Innovation and Entrepreneurship. Springer, New York, NY.

ELLIS, J. B., \& VAN DYNE, L. (2009). Voice and Silence as Observers' Reactions to Defensive Voice: Predictions Based on Communication Competence Theory, Voice and Silence in Organizations, Eds. Jerald Greenberg ve Marissa S. Edwards, Emerald Group Publishing.

EKVALL, G. (1996). “Organisational Climate for Creativity and Innovation”, European Journal of Work and Organisational Psychology, 5 (1), 105-123.

FARRELL, D., \& RUSBULT C. E. (1992). "Exploring the Exit, Voice, Loyalty, and Neglect Typology: The Influence of Job Satisfaction, Quality of Alternatives, and Investment Size”, Employee Responsibilities and Rights Journal, 5, 201-218.

GOLEMAN, D. (2000). İş Başında Duygusal Zekâ, (çev. Handan Balkara), 2. Basım, Varlık Yayınları, İstanbul.

GOLEMAN, D. (2002). Liderlik Tarzları Sonuç Alıcı Liderlik, Harvard Business Review “Lideri Lider Yapan Nedir ?”, (Çev: Nurettin El Hüseyni) Mess Yayınları, İstanbul.

GÖKTAŞ KULUALP, H. (2016). “Çalışan Sesliliği ile Bazı Kişisel ve Örgütsel Özellikler Arasındaki İlişkinin Belirlenmesi: Öğretim Elemanları Üzerine Bir Araştırma”, Ege Akademik Bakış, 16 (4), 745-761.

GRANT, A. M. (2013). "Rocking The Boat But Keeping It Steady: The Role Of Emotion Regulation In Employee Voice”, Academy of Management Journal, 56(3), 1703-1723.

GÜNDÜZ, Ş. (2017). “The Relationship Between Spiritual Leadership and Organizational Cynicism: The Moderating Effect of Emotional Intelligence”, Doğuş Üniversitesi Dergisi, 18(2), 117-132.

GÜNDÜZ ÇEKMECELİOĞLU, H. (2002). "Bireysel, Örgütsel Yaratıcılık ve Yaratıcılık İçin İş Çevresinin Düzenlenmesi, Bir Araştırma”, Yayınlanmamış Doktora Tezi, Gebze Yüksek Teknoloji Enstitüsü.

GÜNDÜZ ÇEKMECELİOĞLU, H. (2006). “Örgüt İklimi, Duygusal Bağlılık ve Yaratıcılık Arasındaki İlişkilerin Değerlendirilmesi: Bir Araştırma”, Atatürk Üniversitesi İktisadi ve İdari Bilimler Dergisi, 20(2), 295-310.

GÜRKAN, G. Ç., \& KOÇOĞLU, M. (2014). "Yaratıcı Örgüt İkliminin Kariyer Tatmini Üzerine Etkisinde Duygusal Bağlılığın Aracı Değişken Rolü: Türkiye'de Bir Vakıf ve 
Bir Devlet Üniversitesinde Karşılaştırmalı Bir Araştırma”, Journal of International Social Research, 7(29), 588-602.

KOÇEL, T. (2005). İşletme Yöneticiliği, 10. Baskı, Arıkan Yayıncılık, İstanbul.

HSIN-HUA, H. (2012). “Authentic Leadership and Employee Voice Behavior: A Multi-Level Psychological Process”, J Bus Ethics, 107, 349-361.

ISAKSEN, S. G. (2017). Leadership's Role in Creative Climate Creation. In Handbook of Research on Leadership and Creativity. Edward Elgar Publishing.

JHA, N., POTNURU, R. K. G., SAREEN, P., \& SHAJU, S. (2019). "Employee Voice, Engagement and Organizational Effectiveness: A Mediated Model", European Journal of Training and Development.

LAM, L. W., LOI, R., CHAN, K. W., \& LIU, Y. (2016). "Voice More and Stay Longer: How Ethical Leaders Influence Employee Voice and Exit Intentions", Business Ethics Quarterly, 26(3), 277-300.

LAW, K. S., WONG, C., \& SONG, L. J. (2000). "The Construct and Criterion Validity of Emotional Intelligence and Its Potential Utility For Management Studies", Journal of Applied Psychology, 89(3), 483-496.

LEPINE, J. A., \& VAN DYNE, L. (2001). "Voice and Cooperative Behavior as Contrasting Forms of Contextual Performance: Evidence of Differential Relationships with Big Five Personality Characteristics and Cognitive Ability", Journal of Applied Psychology, 86(2), 326-336

LIU, J., \& GU, J. (2018). "Supervisor Developmental Feedback, Job Involvement and Employee Voice: The Moderating Role of Employee Emotional Intelligence", Management Review, 30, 128-139.

LIU, W., ZHU, R., \& YANG, Y. (2010). "I Warn You Because I Like You: Voice Behavior, Employee İdentifications, And Transformational Leadership", The Leadership Quarterly, 21 (1), 189-202.

LING, Y., \& LIU, Z. (2016). “The Relationship Between Organizational Ethical Climate and Employee Voice Behavior Under the Perspective of Psychological Safety”, Human Resources Developmen of Chine, 5, 48-54.

LUNDMARK, E., \& BJÖRKMAN, H. (2011). "New Job - New İdeas: The Relationship Between Tenure And Perceived Creative Climate", Human Resource Development Journal, 14(5), 605-621.

MAKENS, M. A. (2016). Employee Voice: The Roles of Organizational Identification, Informational Justice And Power Distance (Master dissertation).

MORGAN, G. A., LEECH, N. L., GLOECKNER, G. W., \& BARRETT, K. C. (2004). SPSS for Introductory Statistics: Use and Interpretation. Lawrence Erlbaum Associates Publishers, New Jersey.

MORRISON, E.W. (2011), "Employee Voice Behavior: Integration and Directions for Future Research", Academy of Management Annals, 5(1), 373-412. 
MORRISON, E. W., \& MILLIKEN, F. J. (2000). “Organisational Silence: A Barrier To Change And Development in Pluralistic World", Academy of Management Review, 25(4), 706-725.

MUMFORD, M. D., \& GUSTAFSON, S. B. (1988). "Creativity Syndrome: Integration, Application, and Innovation”, Psychological Bulletin, 103(1), 27-43.

NOVITA, A. C., MUSNADI, S., \& IBRAHIM, M. (2018). "The Role of İntelligence as a Moderator and Negative Affectivity as a Mediating Variable in the Relationship Between Behavioral Incivility and Counterproductive Work Behavior", European Journal of Business, Economics and Accountancy, 6(4), 53-60.

O'BOYLE JR, E. H., HUMPHREY, R. H., POLLACK, J. M., HAWVER, T. H., \& STORY, P. A. (2011). "The Relation Between Emotional Intelligence and Job Performance: A Meta-Analysis", Journal of Organizational Behavior, 32(5), 788-818.

OLSSON, A., B. PAREDES, K. M., JOHANSSON, U., OLANDER ROESE, M., \& RITZÉN, S. (2019). “Organizational Climate For Innovation And Creativity-A Study in Swedish Retail Organizations", The International Review of Retail, Distribution and Consumer Research, 29(3), 243-261.

PRASADIKA, G. H. H. P., \& NISHANTHI, H. M. (2018). "Perceived Employee Voice and Organizational Commitment: A Case of Sri Lanka”, Asian Journal of Empirical Research, 8(9), 330-341.

PRENTICE, C. (2013), "Emotional Labour and its Consequences: The Moderating Effect of Emotional Intelligence", Individual Sources, Dynamics, and Expressions of Emotion (Research on Emotion in Organizations, Vol. 9), 187-201.

RUCK, K., WELCH, M., \& MENARA, B. (2017). “Employee Voice: An Antecedent to Organizational Engagement?”, Public Relations Review, 43(5), 904-914.

SALOVEY, P., \& MAYER, J. D. (1990). “Emotional Intelligence”, Imagination, Cognition and Personality, 9(3), 185-211.

SAUNDERS, D. M., SHEPPARD, B. H., KNIGHT, V., \& ROTH, J. (1992). "Employee Voice to Supervisors", Employee Responsibilities and Rights Journal, 5(3), 241-261.

SCHUTTE, N. S., MALOUFF, J. M., HALl, L. E., HAGGERTY, D. J., COOPER, J. T., GOLDEN, C. J., \& DORNHEIM, L. (1998). "Development and validation of a Measure of Emotional Intelligence", Personality and Individual Differences, 25, 167177.

SHALLEY, C., GILSON, L., \& BLUM, T. (2000). "Matching Creativity Requurrements And The Work Environment: Effects On Satisfaction And Intentions To Leave”, Academy Of Management Journal, 43(2), 215-223.

STAMPER, C., \& VAN DYNE, L. (2001). "Work Status and Organizational Citizenship Behavior: A Field Study of Restaurant Employees", Journal of Organizational Behavior, 22, 517-536. 
SUNDGREN, M., DIMENÄS, E., GUSTAFSSON, J. E., \& SELART, M. (2005). "Drivers of Organizational Creativity: A Path Model of Creative Climate İn Pharmaceutical R\&D”, R\&D Management, 35(4), 359-374.

SWAIN, A. L. (2019). “The Relationship Between Managers' Emotional Intelligence and Employee Voice”, Doktora Tezi, Chicago Profesyonel Psikoloji Fakültesi, ABD.

TANGIRALA, S., \& RAMANUJAM, R. (2008). "Employee Silence On Critical Work Issues: The Cross Level Effects Of Procedural Justice Climate", Personnel Psychology, 61, 37-68.

THIRUVENKADAM, T., \& SAMPATH KUMAR, K. (2018). “Organizational Climate For Innovation And Creativity”, BVIMSR's Journal of Management Research, 10(2), 165 173.

THOHIROH, A., \& SATRYA, A. (2019). "The Influence of Employee Voice and Employee Resilience to Turnover Intention through Emotional Exhaustion as Mediator on Industrial Garment Workers in Indonesia", International Journal of Scientific \& Engineering Research, 10(1), 8-13.

TUCKER, S., CHMIEL, N., TURNER, N., HERSHCOVIS, M. S., \& STRIDE, C. B. (2008). "Perceived Organizational Support for Safety and Employee Safety Voice: The Mediating Role of Coworker Support for Safety", Journal of Occupational Health Psychology, 13(4), 319-330.

VAN DYNE, L., \& LE PINE, J. A. (1998). "Helping and Voice Extra-Role Behaviors: Evidence of Construct and Predictive Validity", Academy of Management Journal, 41, 108-119.

WALUMBWA, F. O., \& SCHAUBROECK, J. (2009). "Leader Personality Traits And Employee Voice Behavior: Mediating Roles of Ethical Leadership And Work Group Psychological Safety", Journal of Applied Psychology, 94, 1275-1286.

WANG, Z., XU, S., SUN, Y., \& LIU, Y. (2019). "Transformational Leadership and Employee Voice: An Affective Perspective", Frontiers of Business Research in China, 13(2), 1-14.

WHITNEY, M. J., \& COOPER, W. H. (1989). "Predicting Exit, Voice, Loyalty, And Neglect", Administrative Science Quarterly, 34, 521-539.

WOODMAN, R. W., SAWYER, J.E., \& GRIFFIN R. W. (1993). "Toward A Theory Of Organizational Creativity”, Academy of Management Review, 18,(2), 293-317.

YILMAZ, C., FİDAN, Y., \& YILDIRAN, C. (2014). "Duygusal Zekâ ve Örgüt İklimine Etkisi", Business \& Management Studies: An International Journal, 2(3), 243-261.

YIN, L. C. (2010). "Emotional Intelligence as a Moderator in the Relationship Between Negative Emotions and Counterproductive Work Behaviours", A Project Submitted to the School of Business, Hong Kong Baptist University, Hong Kong,

ZENGIN, Y. (2019). "The Effect Of Dark Leadership On Organizational Voice And Job Satisfaction", KAUJEASF, 10(19), 310-337. 